\title{
Geochemistry of Neogene Mudrocks from Sitakund Anticline, Bengal Basin: Implications for Provenance, Weathering, Tectonic Setting and Depositional Environment
}

\author{
Md. Yousuf Gazi'1, S. M. Mainul Kabir¹, Md. Badrul Imam¹, Aminur Rahman², Md. Ashraful Islam1 \\ ${ }^{1}$ Department of Geology, University of Dhaka, Dhaka, Bangladesh \\ ${ }^{2}$ Institute of Mining, Mineralogy and Metallurgy, Joypurhat, Bangladesh \\ Email: yousufspe@gmail.com, smkabir@du.ac.bd,badrul@du.ac.bd, aminur08@gmail.com, ashrafhimel@du.ac.bd
}

How to cite this paper: Gazi, Md.Y., Kabir, S.M.M., Imam, Md.B., Rahman, A. and Islam, Md.A. (2017) Geochemistry of Neogene Mudrocks from Sitakund Anticline, Bengal Basin: Implications for Provenance, Weathering, Tectonic Setting and Depositional Environment. Journal of Geoscience and Environment Protection, 5, 147-171. https://doi.org/10.4236/gep.2017.56015

Received: March 31, 2017

Accepted: June 16, 2017

Published: June 19, 2017

Copyright () 2017 by authors and Scientific Research Publishing Inc. This work is licensed under the Creative Commons Attribution International License (CC BY 4.0).

http://creativecommons.org/licenses/by/4.0/

\begin{abstract}
Geochemical analysis of Neogene mudrocks from Sitakund anticline, Chittagong Tripura Fold Belt (CTFB), Bengal Basin, Bangladesh, was deployed to delineate the provenance, tectonics and depositional environments. Representative samples went through mineralogical and geochemical analysis concerning major, trace and rare earth element analysis. Rigaku ZSX Primus and NITON XL3t 800 XRF instruments were utilized for the determination of major and trace elements. The experiment results reveal that the Neogene mudrocks are rich in silica having concentration of $58.10 \%$ to $62.60 \%$ with an average of $59.90 \%$. Therefore, the geochemical response from the experiments apparently proved the existence of the active continental margin setting for the Neogene mudrocks. Different concentrations and ratios of major oxides satisfy that the mudrocks were derived from felsic source rocks. In addition, chemical index of alteration (CIA) values for the Neogene mudrocks vary from 67.81 to 77.57 with an average 74.41 indicating significant weathering at the source areas. Moreover, $\mathrm{U} / \mathrm{Th}, \mathrm{Cu} / \mathrm{Zn}, \mathrm{Ni} / \mathrm{Co}$ and $\mathrm{V} / \mathrm{Cr}$ ratios designate that the mudrocks were deposited in oxidizing depositional environment.
\end{abstract}

\section{Keywords}

Geochemistry, Neogene mudrocks, Tectonic setting, Provenance, Weathering, Depositional Environment, Sitakund Anticline and Bengal Basin

\section{Introduction}

The study shows the detail geochemical composition of Neogene mudrocks sampled from the Sitakund anticline, Bengal Basin. In this study, mudrocks were 
sampled because of growing interest on mudrock geochemistry. Tertiary-Recent shallow-marine to continental clastic sediments and some minor shelf carbonates in the Bengal Basin, Bangladesh are considered to represent the erosional detritus from a growing Himalayas to the north and the Indo-Burman ranges to the east [1]. The Neogene mudrocks have been selected because the huge pile of Neogene sediments $(\sim 4 \mathrm{~km})$ record uplift and exhumation history of Himalaya and Indo-Burman Ranges. Moreover, the bulk of the deltaic deposits is Miocene and younger. These thick accumulations of inter-bedded mudstones and sandstones were deposited during repeated transgression and regression.

The geochemistry of the mudrocks is of greater importance, because such kind of studies can provide crucial information regarding the provenance, tectonic setting and weathering history of the source rocks. Bhatia (1985) [2] distinguished four tectonic provinces of mudrocks (oceanic island arc, continental island arc, active continental margin, passive margin) based on the parameters of trace element geochemistry. Roser and Korsch (1986) [3] reinforced passive margin (PM), active continental margin (ACM) and oceanic island arc (ARC) settings by means of the $\mathrm{K}_{2} \mathrm{O} / \mathrm{Na}_{2} \mathrm{O}$ ratio and $\mathrm{SiO}_{2}$ content of published data from ancient sedimentary suites. Roser and Korsch (1988) [4] used a discriminant function analysis of major elements $\mathrm{TiO}_{2}, \mathrm{Al}_{2} \mathrm{O}_{3}, \mathrm{Fe}_{2} \mathrm{O}_{3}$ tot., $\mathrm{MgO}, \mathrm{CaO}, \mathrm{Na}_{2} \mathrm{O}$ and $\mathrm{K}_{2} \mathrm{O}$ for sandstones and argillites of selected New Zealand terranes, in discerning four different provenance groups: 1) mafic, 2) intermediate-mostly andesitic detritus, 3) felsic, plutonic and volcanic detritus and 4) recycled-mature polycyclic quartzose detritus from sandstones and argillites of designated New Zealand terranes.

Chemical composition of rocks generally preserves the evolutionary process and significant depositional event of sedimentary rock suits. Several researchers have recommended that major element geochemistry of sedimentary rocks is more suitable in discriminating a tectonic setting [3] [5]; however, major trace elements, such as $\mathrm{La}, \mathrm{Y}, \mathrm{Sc}, \mathrm{Cr}$, Th, $\mathrm{Zr}$, Hf and $\mathrm{Nb}$, principally in grouping with $\mathrm{TiO}_{2}$, are finest suited for provenance and tectonic setting delineation studies because of their comparatively low mobility during deposition of sedimentary sequence [6]. Tectonic setting influence the significant variation in composition of sedimentary rocks. Passive margin sediments are typified by felsic composition whereas active margin or arc sediments are characteristically enriched in mafic components [7] [8]. Immobile trace elements, rare earth elements (REEs), and major elements are consistent indicators in the assessment of tectonic setting, weathering processes, and provenance [2]-[14]. Degree of weathering can be valued with the help of the Chemical Index of Alteration (CIA) and Th/U, $\mathrm{Th} / \mathrm{Sc}$, and $\mathrm{Zr} / \mathrm{Sc}$ ratios in the source area [8] [10]. It is customary that sandstones in a given sequence have lower CIA (Chemical Index of alteration) indices than inter-bedded muds, as sands are feldspar rich, whereas muds contain more of the clay weathering products. In this condition, the CIA ratios in the Mudrocks are a more exact measure of the intensity of source weathering. Some authors have used geochemical parameters to comprehend ancient sedimentspaleo-oxygenation conditions [15] [16] [17] [18] [19] [20]. The aim of this 
study is to gain insight into the provenance, tectonic setting, source area weathering and paleo-environmental conditions of the Neogene mudrocks in the Bengal basin using their major, trace and rare earth elements abundance.

\section{Geologic Settings}

The Sitakund anticline is positioned within the Chittagong Tripura Fold Belt (CTFB) of the Bengal basin is the youngest structural feature of the western flank of the Indo-Burmanranges (Figure 1). Bengal basin evolution initially from late Jurassic to early Cretaceous is directly connected with the break-up of eastern Gondwanaland and collision of the Indian plate with Burmese plate to the east the Asian plate to the north. Chittagong Tripura Fold Belt (CTFB) is characterized by N-S trending hills composed of sedimentary piles ranging in age from Miocene to Recent [21] (Table 1).

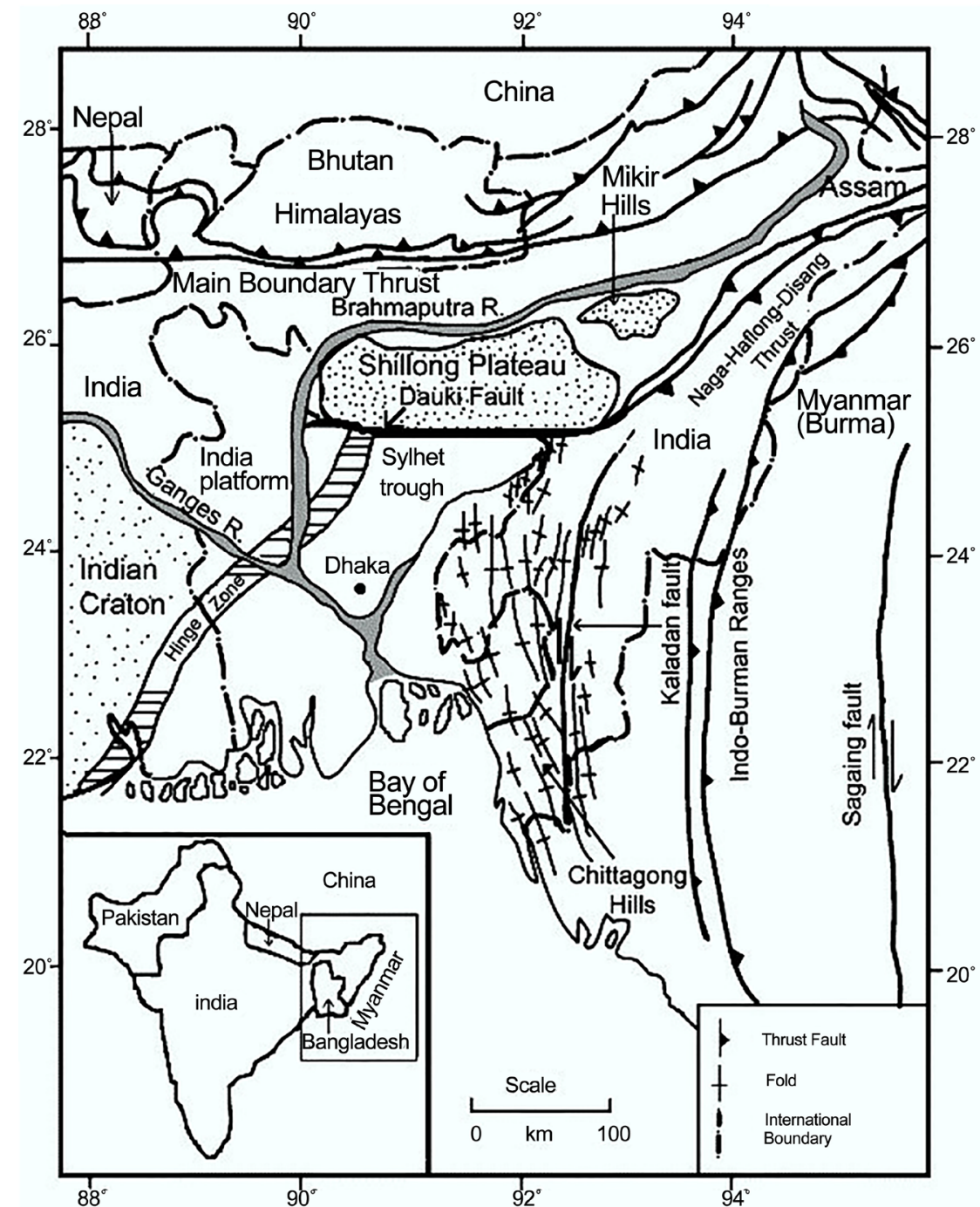

Figure 1. Major tectonic elements encompassing the Bengal basin and its surrounding. Hinge zone separate the Geosynclinal basin from the Indiancraton. Right-lateral NS trending faults (e.g., Kaladan fault) located in the east. The Dauki fault splits the Sylhet trough from the raised Shillong Plateau at the north [24]. 
Sitakund, Kailastila, Lalmai, and certain other anticlinal structures cover the west zone of the folded belt [22]. It is documented that the Indian plate had progressed from south to north, on the other hand, Burmese plate had forwarded from east to west. The relative movement has created the main east-west trending horizontal compression in the area. In the east, the amount of the compressional force was greater compared to the west. Key pushing agent in the plate movements resulted from differential compression was due to overriding of Burmese plate on to the Indian plate [23]. During the span of the tectonic history of the area both plates were drifted east and north-eastward towards the relative stable Shan Tenasserim block. This tectonic force was the chief driving mechanism behind the development of the NNW-SSE trending fold belt and thrusts of the CTFB. Sitakund anticline is also the result of this prehistoric compression tectonics.

\section{Materials and Method}

The carefully chosen samples were crushed for 20 minutes in a planetary ball mill (PM-200, Retsch, Germany) to transform powder form in mixing environments. The powder samples were then pulverized that is subjected to a pulverizer machine. The finely ground powder $(<100 \mu \mathrm{m})$ was then placed in a porcelain crucible and oven dried at temperature of $1000 \mathrm{C}$ overnight to get rid of moisture content. The dried powder samples were mixed with binder (steric acid: Ratio of 1:10) and grounded for two minutes. The resultant mixture was served into an aluminum cap $(30 \mathrm{~mm})$. The cap was crammed between two tungsten carbide pellets by a manual hydraulic press with 10 - 15 tons/sq. in. for 2 minutes and in conclusion, pressure was unrestricted slowly. The pellet was then prepared for $\mathrm{X}$-ray fluorescence treatments. The elements measured by X-ray fluorescence (XRF) Spectrometer method at IMMM, BCSIR, Joypurhat following the procedures of Goto \& Tatsumi (1994) [26] using Rigaku ZSX Primus XRF machine armed with an end window 4 . $\mathrm{kW}$ Rh-anode X-ray tube. The heavy and light elements were documented using $40 \mathrm{kV}$ and $30 \mathrm{kV}$ voltage with $60 \mathrm{~mA}$ and $100 \mathrm{~mA}$ current consecutively. The prepared samples were also analyzed for trace element using NITON XL3t 800 Analyzer in Sediment Repository Lab, department of Geology, University of Dhaka.

Table 1. Stratigraphicarrangement of Sitakund anticline, Eastern Fold Belt (EFB) modified from Akhter, S. H. (1979) [25].

\begin{tabular}{cccc}
\hline Age (approx.) & Group & Formation & Thickness (approx.) (m) \\
\hline Recent & & Alluvium & \\
Plio-Pleistocene & & Dupitila & 500 \\
& Tipam & Girujan Clay & 30 \\
Pliocene & Group & Tipam & 1250 \\
& Surma & Bokabil & 2700 \\
Miocene & Group & Bhuban & 640 \\
\hline
\end{tabular}




\section{Results}

\subsection{Major Elements}

Major and trace element composition of sediments provides clue to the tectonic setting, weathering, paleo-oxygenation condition during sedimentation and provenance. (Table 2) shows the major oxide analysis (whole-rock geochemical analysis) of sixteen Neogene mudrocks, summarizes the average major element oxide (wt. \%) data for the samples being studied. Mean major elemental composition of the Neogene mudrocks is in reasonable correspondence to the average shale narrated by Wedepohl (1971) [27], NASC (North American Shale Composite), [28], UC (the upper crust, [11]) with the exclusion of the low content of $\mathrm{CaO}$ (Table 3 ) but compared with PASS (Post-Archaean Shale, Taylor and McLennan, 1985 [11]), the Neogene mudrocks are slight depleted in $\mathrm{Al}_{2} \mathrm{O}_{3}$ content. The $\mathrm{CaO}$ diminution of the Neogene mudrocks is linked to the scarceness of calcic minerals [12].

The Neogene mudrocks samples show no clear difference in major chemical composition from younger to older. $\mathrm{SiO}_{2}$ content of the Neogene mudrocks was found to be high (ranging from $58.10 \%$ to $62.60 \%$, with an average $59.90 \%$ ). The $\mathrm{TiO}_{2}$ content varies from 0.88 to $1.10 \mathrm{wt} . \%$, the $\mathrm{Al}_{2} \mathrm{O}_{3}$ content from 18.60 to 20.89 wt.\%, and the $\mathrm{Fe}_{2} \mathrm{O}_{3}$ content ranges from 7.74 to 9.67 wt.\%. The CaO content is low (0.93 to $3.18 \mathrm{wt} . \%$; av. $1.84 \mathrm{wt} . \%$ ). Lesserconcentrations have noticed for $\mathrm{MnO}, \mathrm{CaO} \mathrm{TiO}_{2}$ and $\mathrm{P}_{2} \mathrm{O}_{5}(0.12 \%, 1.84 \%, 1.01 \%$, and $0.17 \%$ respectively). The observed relative enrichment in $\mathrm{Al}_{2} \mathrm{O}_{3}$ and $\mathrm{K}_{2} \mathrm{O}$ is linked with the raised up of

Table 2. Chemical composition of the Neogene mudrocks from Sitakund anticline (Major Oxides concentration in wt.\%).

\begin{tabular}{|c|c|c|c|c|c|c|c|c|c|c|c|c|c|c|}
\hline \multicolumn{2}{|c|}{ Major Elements } & \multirow{2}{*}{$\begin{array}{c}\mathrm{SiO}_{2} \\
62.60\end{array}$} & \multirow{2}{*}{$\begin{array}{r}\mathrm{Al}_{2} \mathrm{O}_{3} \\
18.60\end{array}$} & \multirow{2}{*}{$\frac{\mathrm{Fe}_{2} \mathrm{O}_{3}}{8.23}$} & \multirow{2}{*}{$\begin{array}{c}\mathrm{MnO} \\
0.083\end{array}$} & \multirow{2}{*}{$\frac{\mathrm{MgO}}{2.688}$} & \multirow{2}{*}{$\begin{array}{c}\mathrm{CaO} \\
0.932\end{array}$} & \multirow{2}{*}{$\frac{\mathrm{Na}_{2} \mathrm{O}}{1.098}$} & \multirow{2}{*}{$\begin{array}{r}\mathrm{K}_{2} \mathrm{O} \\
4.00\end{array}$} & \multirow{2}{*}{$\begin{array}{r}\mathrm{TiO}_{2} \\
1.02\end{array}$} & \multirow{2}{*}{$\begin{array}{l}\text { LOI } \\
0.55\end{array}$} & \multirow{2}{*}{$\frac{\mathrm{P}_{2} \mathrm{O}_{5}}{0.196}$} & \multirow{2}{*}{$\begin{array}{c}\text { CIA } \\
77.57\end{array}$} & \multirow{2}{*}{$\begin{array}{l}\text { Total } \\
99.44\end{array}$} \\
\hline & LC-1 & & & & & & & & & & & & & \\
\hline & LC-8 & 60.60 & 18.68 & 8.111 & 0.127 & 2.706 & 2.807 & 0.863 & 4.43 & 1.05 & 0.47 & 0.148 & 71.06 & 99.52 \\
\hline & LC-10 & 59.77 & 20.77 & 8.76 & 0.141 & 2.41 & 1.143 & 0.803 & 4.67 & 0.939 & 0.42 & 0.169 & 77.43 & 99.57 \\
\hline & BC-3 & 60.26 & 19.21 & 9.12 & 0.122 & 2.639 & 1.786 & 0.884 & 4.21 & 1.09 & 0.48 & 0.196 & 75.52 & 99.51 \\
\hline & BC-5 & 58.56 & 20.09 & 9.455 & 0.144 & 2.884 & 1.528 & 1.090 & 4.36 & 1.103 & 0.58 & 0.198 & 76.07 & 99.41 \\
\hline & BC- 6 & 59.08 & 19.84 & 8.969 & 0.150 & 3.112 & 1.798 & 1.210 & 4.31 & 0.887 & 0.44 & 0.198 & 74.87 & 99.55 \\
\hline & BC-7 & 59.67 & 19.26 & 8.915 & 0.147 & 3.00 & 1.893 & 1.094 & 4.24 & 0.992 & 0.59 & 0.199 & 74.58 & 99.41 \\
\hline Sample & BC-11 & 61.97 & 16.84 & 7.745 & 0.100 & 2.845 & 3.184 & 1.181 & 4.17 & 1.00 & 0.80 & 0.163 & 67.81 & 99.19 \\
\hline \multirow[t]{9}{*}{ ID } & BC-13 & 60.21 & 19.22 & 8.548 & 0.120 & 3.144 & 1.773 & 1.120 & 4.21 & 0.905 & 0.57 & 0.171 & 74.63 & 99.42 \\
\hline & $\mathrm{BK}-1$ & 60.36 & 19.01 & 8.892 & 0.134 & 2.841 & 1.534 & 1.239 & 4.18 & 1.036 & 0.60 & 0.166 & 74.81 & 99.39 \\
\hline & BK-8 & 57.25 & 20.89 & 9.674 & 0.164 & 3.435 & 1.361 & 0.985 & 4.43 & 1.071 & 0.54 & 0.197 & 77.34 & 99.45 \\
\hline & BK-9 & 58.10 & 20.72 & 9.411 & 0.133 & 2.917 & 1.343 & 1.054 & 4.54 & 1.017 & 0.59 & 0.168 & 76.46 & 99.40 \\
\hline & MC-6 & 62.34 & 17.51 & 8.112 & 0.103 & 2.941 & 2.239 & 1.025 & 4.05 & 0.991 & 0.53 & 0.158 & 72.06 & 99.46 \\
\hline & S-1 & 59.55 & 19.32 & 8.419 & 0.162 & 2.552 & 3.149 & 0.816 & 4.41 & 0.982 & 0.46 & 0.179 & 71.29 & 99.53 \\
\hline & S-4 & 59.02 & 19.89 & 8.400 & 0.114 & 3.194 & 1.934 & 1.056 & 4.61 & 1.028 & 0.59 & 0.163 & 73.81 & 99.40 \\
\hline & S-7 & 59.19 & 19.53 & 8.852 & 0.111 & 2.609 & 1.189 & 1.184 & 4.61 & 1.073 & 1.48 & 0.171 & 75.28 & 98.51 \\
\hline & Average & 59.90 & 19.33 & 8.72 & 0.12 & 2.86 & 1.84 & 1.04 & 4.33 & 1.01 & 0.60 & 0.17 & 74.41 & 99.39 \\
\hline
\end{tabular}


Table 3. Average composition of the Neogene mudrocks from Sitakund anticline and compared with those of PASS (Post-Archaean Shale, Taylor and McLennan, 1985 [11]), NASC (North American Shale Composite, Gromet et al., 1984 [28]), UC (Upper Crust, Taylor and McLennan, 1985 [11]) and Wedepohl (1971) [27].

\begin{tabular}{cccccc}
\hline $\mathrm{Wt} . \%$ & $\begin{array}{c}\text { Neogene mudrocks from } \\
\text { Sitakund Anticline }\end{array}$ & NASC & PASS & Wedepohl & UC \\
\hline $\mathrm{SiO}_{2}$ & 59.90 & 64.80 & 62.80 & 58.9 & 66.00 \\
$\mathrm{TiO}_{2}$ & 1.01 & 0.70 & 1.00 & 0.78 & 0.50 \\
$\mathrm{Al}_{2} \mathrm{O}_{3}$ & 19.33 & 16.90 & 18.90 & 16.7 & 15.20 \\
$\mathrm{Fe}_{2} \mathrm{O}_{3}$ & 8,72 & 5.65 & 7.22 & 6.91 & 5.00 \\
$\mathrm{MnO}$ & 0.12 & 0.06 & 0.11 & 0.09 & 0.08 \\
$\mathrm{MgO}$ & 2.86 & 2.86 & 2.20 & 2.6 & 2.20 \\
$\mathrm{CaO}$ & 1.84 & 3.63 & 1.30 & 2.2 & 4.20 \\
$\mathrm{Na}_{2} \mathrm{O}$ & 1.04 & 1.14 & 1.20 & 1.6 & 3.90 \\
$\mathrm{~K}_{2} \mathrm{O}$ & 4.33 & 3.97 & 3.70 & 3.6 & 3.40 \\
$\mathrm{P}_{2} \mathrm{O}_{5}$ & 0.17 & 0.13 & 0.16 & 0.16 & - \\
\hline
\end{tabular}

$\mathrm{K}$-feldspar, mica and other clay minerals. Diminution of $\mathrm{Na} 2 \mathrm{O}$ and $\mathrm{CaO}$ is ascribed to minor abundance of plagioclase feldspar. Lower $\mathrm{CaO}$ content also indicate no associated carbonates or dolomitization. The poorer feldspar concentration are possibly a result either of weathering processes or the feldspar depletingsource region [5] [12] [13]. Harker Diagrams illustrates the fluctuation in the major elements concentration of Mudrocks relative to $\mathrm{SiO}_{2}$ [4] [5]. Plots of $\mathrm{TiO}_{2}, \mathrm{Al}_{2} \mathrm{O}_{3}, \mathrm{Fe}_{2} \mathrm{O}_{3}, \mathrm{~K} 2 \mathrm{O}, \mathrm{Na}_{2} \mathrm{O}, \mathrm{CaO}, \mathrm{MnO}$, and $\mathrm{MgO}$ against $\mathrm{SiO}_{2}$ concentration indicate negative linear patterns (Figure 2). The negative correlation of $\mathrm{SiO}_{2}$ with most major and trace elements is owing to size sorting and quartz dilution all the way through the transportation of these sediments. Amount of $\mathrm{SiO}_{2}$ is a pointer of richness of silicate minerals existing within the Mudrocks with quartz clearly functioning as the noticeable meaning in the exemplification.

$\mathrm{Fe}_{2} \mathrm{O}_{3}+\mathrm{MgO}$ is also well correlated with $\mathrm{Al}_{2} \mathrm{O}_{3}$. The latter correlation implies that these oxides are associated with phyllosilicates, particularly in matrix chlorite [12]. X-ray diffraction patterns also disclose that Neogene mudrocks contain illite-chlorite rich clay minerals. The mudrocks silica to alumina ratio is high (3.11). The 3.11 silica-alumina ratio showed that that the mudrocks samples are highly siliceous. The average $\mathrm{SiO}_{2}$ (59.90\%) and $\mathrm{Al}_{2} \mathrm{O}_{3}$ (19.33\%) chemical composition in mudrocks constituted about $79.23 \%$ of the samples total chemical composition. The other chemical impurities in mudrocks samples from the Sitakund anticline are $\mathrm{Fe}_{2} \mathrm{O}_{3}(8.72 \%)$ and $\mathrm{TiO}_{2}(1.01 \%)$. The ranges of $\mathrm{SiO}_{2} / \mathrm{Al}_{2} \mathrm{O}_{3}$ and $\mathrm{Na}_{2} \mathrm{O} / \mathrm{K}_{2} \mathrm{O}$ values from 62.74 to 3.56 and 0.17 to 0.29 , respectively, suggest that the studied samples represent relatively mature sediments. Variation of major elements is probably a result of sedimentary processes [5]. Sediments $\mathrm{K}_{2} \mathrm{O} /$ $\mathrm{Al}_{2} \mathrm{O}_{3}$ ratio can be used as an indicator of ancient sediments' original composition. The $\mathrm{K}_{2} \mathrm{O} / \mathrm{Al}_{2} \mathrm{O}_{3}$ ratios for clay minerals and feldspars are different (0.0 to 


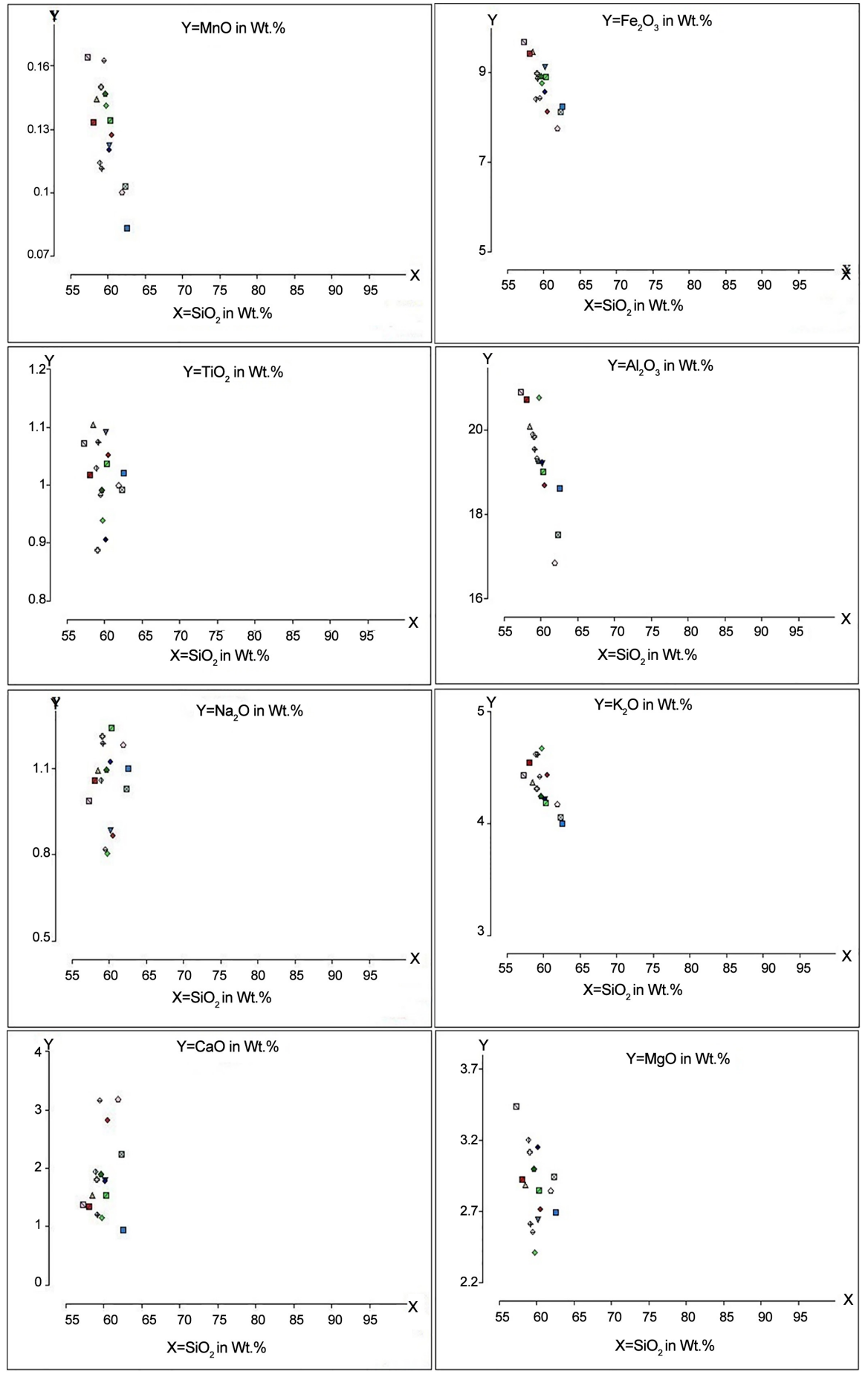

Figure 2. Harker variation diagrams for major elements in the Neogene mudrocks of Sitakund anticline.

$0.3,0.3$ to 0.9 , respectively) according to Cox [29]. The average $\mathrm{K}_{2} \mathrm{O} / \mathrm{Al}_{2} \mathrm{O}_{3}$ ratio for shale varies from 0.21 to 0.24 . The $\mathrm{K}_{2} \mathrm{O} / \mathrm{Al}_{2} \mathrm{O}_{3}$, Shows that the ratio is closer to the lower clay mineral range limit in mudrocks samples.

\subsection{Trace Element Composition}

In the study area, Neogene mudrocks show moderate-to-little discrepancy in 
concentration of trace elements (Table 4). This characteristic signifies shared provenance, weathering, and tectonic setting [5] [7] [13].There is a Positive correlation of $\mathrm{Al}, \mathrm{Cs}, \mathrm{Ba}$, Th, and $\mathrm{U}$ with $\mathrm{K}$ content denotes that concentrations of these elements are controlled by clay and mica contents (Table 5). Additionally, $\mathrm{Zr} / \mathrm{Sc}$ and $\mathrm{Zr} / \mathrm{Hf}$ ratios act as good pointers to observe zircon enrichment [8] [13]. In the studied samples, the high $\mathrm{Zr} / \mathrm{Hf}$ (range of $20.28-47.17$ with an average of 33.84) and $\mathrm{Zr} / \mathrm{Sc}$ (range from 8.45 to 16.25 ) ratios are indicators of zirconenrichment. La/Sc ratio also proposes the rock maturity, usually differs from 3 to 9 [7] [12]. Analyzed mudrocks demonstrate small deviation in La/Sc ratio, which ranges from 1.92 to 3.43 (Table 6). $\mathrm{V}$ and Sc have a tendency to be associated with mafic content. Lower $\mathrm{V}$ and Sc contents in the mudrocks suggest that these samples were derived from V and Sc enriched source rocks [2] [3] [5] [12].

\subsection{Rare Earth Elements}

Chondrite-normalized diagrams illustrate REE patterns in the studied samples (Figure 3). The average REE concentrations of all samples were compared to the Post-Archean average Australian Shale (PAAS), NASC (North American Shale Composite, Gromer et al., 1984 [28]) and the Upper Continental Crust (UCC) concentration values (Taylor and McLennan 1985) [11]. In spite of the differences in the abundance, the samples show similar REE pattern as UC. The Neogene mudrocks show slight LREE enriched.

Table 4. Chemical composition of the Neogene mudrocks from Sitakund anticline (Trace Element concentration in ppm).

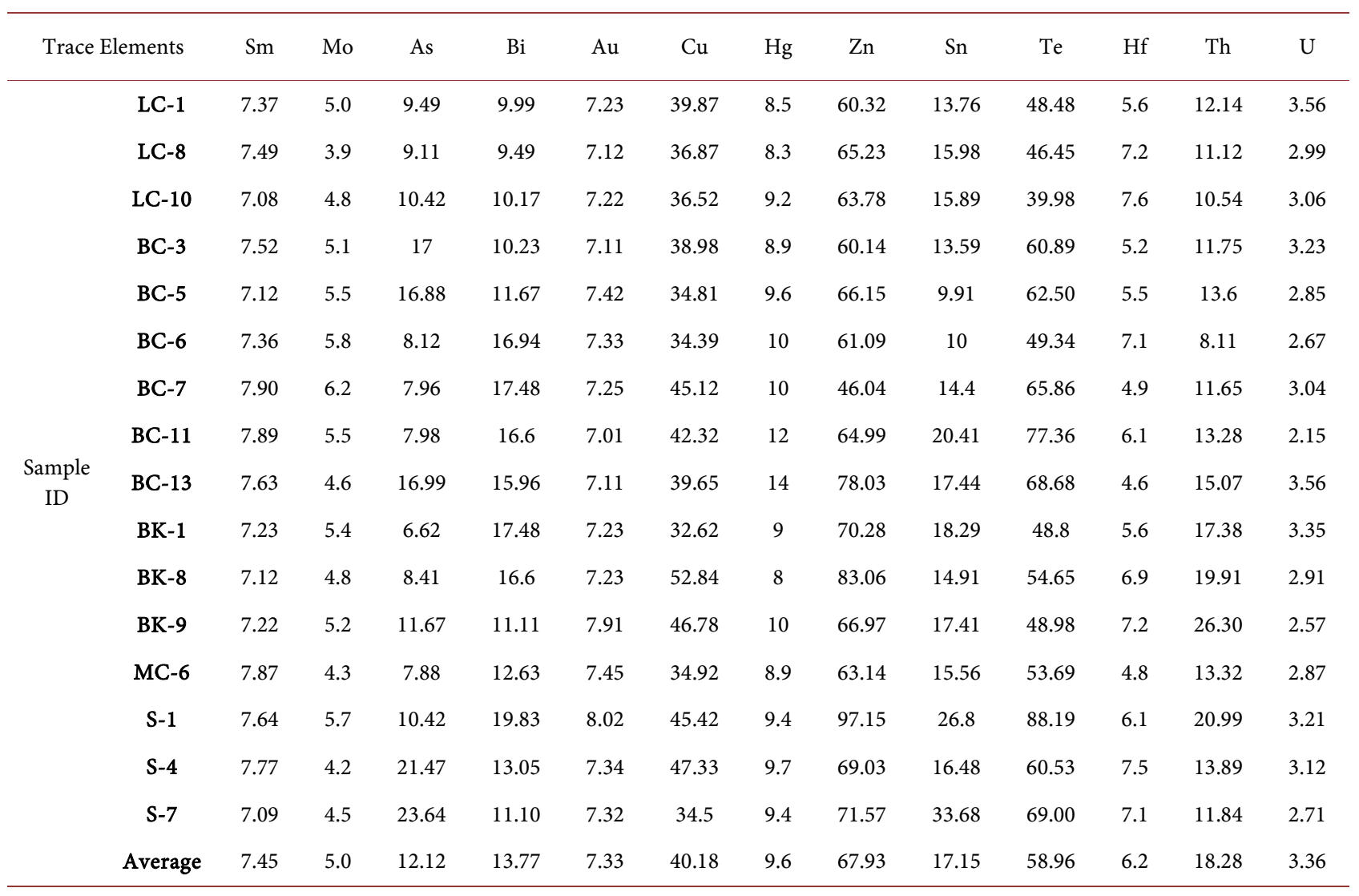


Md. Y. Gazi et al.

Table 5. Chemical composition of the Neogene mudrocks from Sitakund anticline (Trace Element concentration in ppm).

\begin{tabular}{|c|c|c|c|c|c|c|c|c|c|c|c|c|c|c|c|c|}
\hline \multicolumn{2}{|c|}{$\begin{array}{c}\text { Trace } \\
\text { Elements }\end{array}$} & V & $\mathrm{Cr}$ & Co & $\mathrm{Rb}$ & $\mathrm{Sr}$ & $\mathrm{Y}$ & $\mathrm{Zr}$ & $\mathrm{Nb}$ & $\mathrm{Sc}$ & Cs & $\mathrm{Ba}$ & $\mathrm{La}$ & $\mathrm{Ni}$ & $\mathrm{Cd}$ & $\mathrm{Pb}$ \\
\hline \multirow{17}{*}{$\begin{array}{c}\text { Sample } \\
\text { ID }\end{array}$} & LC-1 & 112 & 135 & 16 & 40.78 & 101 & 39.3 & 220 & 17.04 & 17 & 44.78 & 527 & 40.3 & 47.9 & 15 & 22.34 \\
\hline & LC-8 & 102 & 214 & 19 & 35.67 & 109 & 31 & 248 & 14.30 & 20 & 34.78 & 524 & 44.3 & 48.9 & 13 & 28.56 \\
\hline & LC-10 & 110 & 218 & 20 & 29.35 & 119 & 29 & 190 & 10.11 & 18 & 39.97 & 611 & 41.4 & 50.3 & 14 & 18.22 \\
\hline & BC-3 & 96.1 & 162 & 15 & 90.21 & 127 & 29.26 & 214 & 9.8 & 17 & 33.56 & 300 & 49.9 & 93.2 & 11 & 26.28 \\
\hline & BC-5 & 99 & 168 & 13 & 90.31 & 100 & 31.9 & 211 & 9.1 & 15 & 46.6 & 387 & 47.9 & 54.6 & 10 & 27.86 \\
\hline & BC- 6 & 100 & 164 & 21 & 49.68 & 110 & 32.65 & 144 & 11.67 & 16 & 38.03 & 606 & 43.6 & 68.7 & 14 & 21.23 \\
\hline & BC-7 & 79 & 112 & 15 & 52.36 & 103 & 32.11 & 208 & 11.08 & 14 & 53.56 & 546 & 47.8 & 66.2 & 20 & 13.02 \\
\hline & BC-11 & 90.3 & 146 & 13 & 51.32 & 108 & 29.45 & 195 & 11.01 & 12 & 53.57 & 540 & 41.2 & 66.7 & 11 & 17.26 \\
\hline & BC-13 & 92 & 199 & 17 & 51.48 & 100 & 38.96 & 217 & 8.7 & 21 & 59.85 & 674 & 40.4 & 76.4 & 13 & 29.91 \\
\hline & BK-1 & 86.6 & 172 & 18 & 51.46 & 105 & 41 & 248 & 11.22 & 17 & 54.83 & 636 & 41.7 & 65.4 & 21 & 17.56 \\
\hline & BK-8 & 119 & 119 & 15 & 56.68 & 131 & 31.4 & 189 & 11.01 & 16 & 51.21 & 680 & 45.2 & 65.1 & 13 & 29.91 \\
\hline & BK-9 & 133 & 170 & 18 & 49.74 & 107 & 29.8 & 159 & 9.95 & 15 & 39.94 & 632 & 43.1 & 104 & 15 & 26.31 \\
\hline & MC-6 & 91.5 & 200 & 21 & 45.52 & 85 & 35.7 & 216 & 11.5 & 18 & 57.70 & 648 & 46.5 & 59.5 & 14 & 26.87 \\
\hline & S-1 & 122 & 178 & 15 & 60.74 & 105 & 33.75 & 169 & 13.31 & 20 & 59.80 & 802 & 39.8 & 100 & 22 & 48.16 \\
\hline & S-4 & 98.3 & 189 & 14 & 54.97 & 95 & 31.6 & 198 & 11.11 & 17 & 58.96 & 694 & 49.5 & 94.5 & 13 & 26.05 \\
\hline & S-7 & 99.1 & 195 & 17 & 44.69 & 75 & 29.47 & 203 & 8.56 & 15 & 55.54 & 624 & 41.8 & 69.7 & 17 & 14.87 \\
\hline & Average & 101 & 171 & 16 & 53.4 & 105 & 32.89 & 201 & 11.21 & 16.7 & 48.91 & 589 & 44 & 70.6 & 14 & 24.65 \\
\hline
\end{tabular}

Table 6. Range of elemental ratios for felsic and mafic igneous rocks and corresponding upper continental crust values. The table of range of mafic and felsic rocks is after [32] [39]; (Cullers et al. 1988) [41] and the UCC values are after Taylor and McLennan, $1985[11]$.

\begin{tabular}{ccccc}
\hline Elemental Ratios & Neogene mudrocks & Felsic Rocks & Mafic Rocks & UCC \\
\hline Th/Sc & $0.82-1.46$ & $0.84-20.05$ & $0.05-0.22$ & 0.79 \\
$\mathrm{Th} / \mathrm{Co}$ & $0.83-1.45$ & $0.27-19.4$ & $0.04-1.4$ & 0.63 \\
$\mathrm{Cr} / \mathrm{Th}$ & $2.70-12.07$ & $4.00-15.00$ & $25-500$ & 7.76 \\
$\mathrm{La} / \mathrm{Th}$ & $1.89-2.93$ & $25.0-16.3$ & $0.43-0.86$ & 2.21 \\
\hline
\end{tabular}

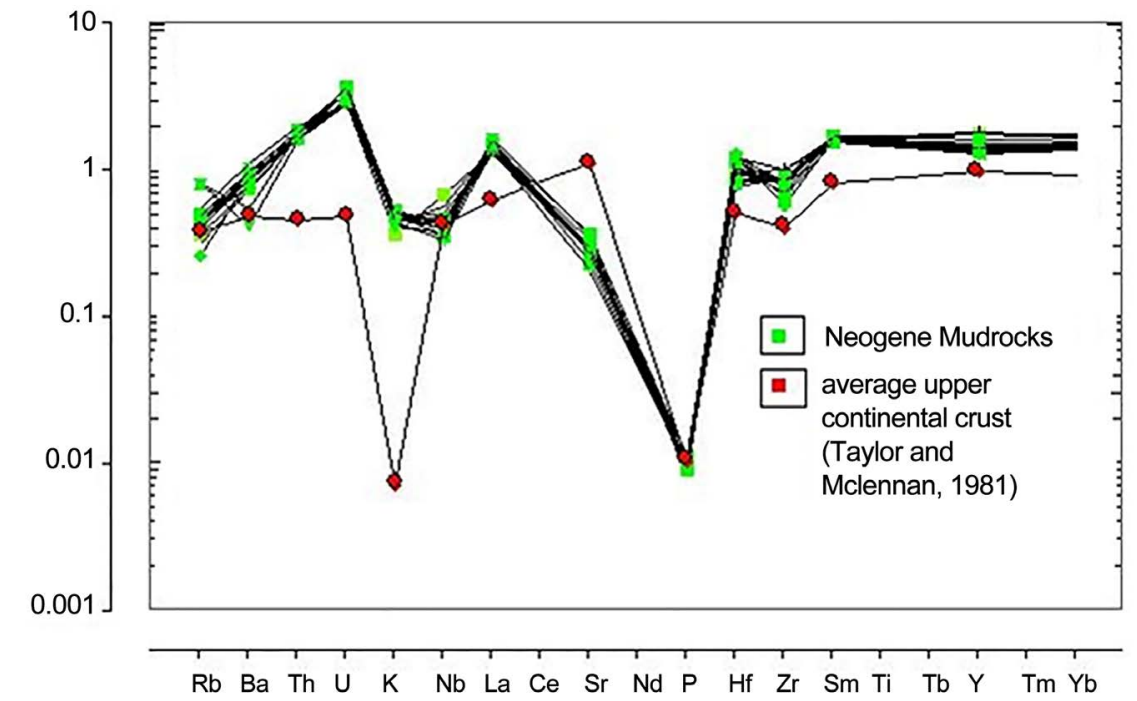

Figure 3. Chondrite normalized diagram for the Neogene mudrocks from Sitakund anticline against upper continental crust [30]. 


\section{Discussion}

\subsection{Provenance}

The geochemical signs of clastic sediments have been used to establish provenance characteristics [11] [19] [31] [32]. Most clastic rocks $\mathrm{Al}_{2} \mathrm{O}_{3} / \mathrm{TiO}_{2}$ ratios are fundamentally used to deduce source rock composition, because $\mathrm{Al}_{2} \mathrm{O}_{3} / \mathrm{TiO}_{2}$ ratios increase from 3 to 8 for mafic igneous rocks, from 8 to 21 for intermediate rocks and from 21 to 70 for felsic igneous rocks [33]. The $\mathrm{Al}_{2} \mathrm{O}_{3} / \mathrm{TiO}_{2}$ oscillated from 17.62 to 22.36 in the Neogene mudrocks. Hence, in this study the $\mathrm{Al}_{2} \mathrm{O}_{3} /$ $\mathrm{TiO}_{2}$ ratio propose felsic rocks as being probable source rocks for the analyzed samples including little intermediate sign in nature. Abundance of $\mathrm{Cr}$ and $\mathrm{Ni}$ in siliciclastic sediments was considered as a useful provenance tool. Low $\mathrm{Cr}$ concentration indicates felsic provenance, according to Wrafter and Graham (1989) [34], and high $\mathrm{Cr}$ and $\mathrm{Ni}$ content is mainly found in ultramafic rock-derived sediment [19]. The $\mathrm{Cr}$ and $\mathrm{Ni}$ content in these mudrocks has found to be low, therefore signifying felsic provenance. The increase in the $\mathrm{Cr}$ and $\mathrm{Ni}$ abundance for passive margin mudrocks is due to the enrichment and adsorption of these elements with the increased phyllosilicate content. Garver et al. (1996) [35] suggested that elevated $\mathrm{Cr}(>150 \mathrm{ppm})$ and $\mathrm{Ni}(>100 \mathrm{ppm})$ and a ratio of $\mathrm{Cr} / \mathrm{Ni}$ between 1.3 - 1.5 are diagnostic of ultramafic rocks in the source region. In comparison, $\mathrm{Cr}$ concentrations ranges from 112 to $120 \mathrm{ppm}$ (average $171.31 \mathrm{ppm}$ ) mostly below $150 \mathrm{ppm}$ and $\mathrm{Ni}$ concentrations ranges from 48.9 to $104 \mathrm{ppm}$ (average $70.69 \mathrm{ppm}$ ) and $\mathrm{Cr} / \mathrm{Ni}$ ratios range from 1.63 to 4.37 , but mostly above 2.0. This comparison suggests that the existence of huge complexes of felsic source but some samples shows mafic/ultramafic rocks signature in the source region. Reduction in $\mathrm{Rb} / \mathrm{Sr}$ and $\mathrm{Ba} / \mathrm{Sr}$ is because of the loss of $\mathrm{Sr}$ and feldspar with cumulative weathering and recycling [2]. The concentrations of $\mathrm{Rb}$ (mean $\sim 53.4$ ppm), Sr ( 105) and Sm ( 7.45) of the Neogene mudrocks are similarto those of sedimentary suits of High Himalayan region [36].

REE, Th and Sc are quite beneficialto infer crustal compositions. This is because of their distribution is not considerably influenced by diagenesis and metamorphism as well as is a lesser amount of effect by heavy mineral fractionation than that for some elements, i.e. Zr, Hf, and Sn [19]. REEs enrichment in sedimentary rock is a pointer to the source area determination. REE patterns represent the features of source rocks geochemical attributes, from which sediments are resulted and accumulate within the basin depositional center. fluctuation in the REE patterns remain constant, if they derive from a common source. On the other hand, REEs show variable patterns in sediments that originated from heterogeneous source rocks [11] [32] [37] [38] [39]. From the chondritenormalized REE plot (Figure 3), average REE concentration in Neogene mudrocks samples reflects a pattern alike to PAAS and UCC. Enrichment of LREEs and concurrent with poor HREE concentration are evidence of a felsic igneous source [11]. Ratios such as $\mathrm{Th} / \mathrm{Sc}, \mathrm{La} / \mathrm{Sc}$, and $\mathrm{Th} / \mathrm{Co}$ are significantly dissimilar in felsic and basic rocks and may limits on average provenance composition [29] 
[32] [40] (Table 7). The Th/Co, Th/Sc and La/Sc ratios for Neogene mudrocks from this study were compared to those of felsic and basic rock- derived sediment (fine fraction) upper continental crust (UCC) and after [32] [39]; (Cullers et al. 1988) [41] (Table 8). These comparisons also specified that such ratios came within the range of felsic source rocks. As a consequence of their immobile characteristic, trace elements in sediments reflect source rock composition.

$\mathrm{Zr}, \mathrm{Nb}, \mathrm{Hf}, \mathrm{U}$, Th and $\mathrm{Y}$ are high field strength elements, which are preferentially partitioned into melts during crystallization. This mechanism results in these elements being enriched in felsic rather than mafic sources. In contrast, $\mathrm{Co}, \mathrm{Sc}$, and $\mathrm{V}$ are more concentrated in mafic than in felsic source rocks [11] [42] [43]. These elements are thought to reflect provenance compositions as a consequence of their generally immobile behavior [11].

Table 7. Mudrocks Elemental ratios paralleled with sediments resulting from felsic, mafic rocks and the upper continental crust. (a) Cullers et al. (1979, 1988) [41] [58]; Cullers (1994, 2000) [18] [39]. (b) Taylor and McLennan (1985) [11]; McLennan (2001) [59].

\begin{tabular}{ccccc}
\hline $\begin{array}{c}\text { Elemental } \\
\text { ratio }\end{array}$ & $\begin{array}{c}\text { Neogene mudrocks } \\
(\mathrm{n}=20)\end{array}$ & $\begin{array}{c}\text { Ranges in sediments from } \\
\text { felsic sources(a) }\end{array}$ & $\begin{array}{c}\text { Ranges in sediments from } \\
\text { mafic sources (a) }\end{array}$ & $\begin{array}{c}\text { Upper continental } \\
\text { crust (b) }\end{array}$ \\
\hline $\mathrm{La} / \mathrm{Sc}$ & $1.92-3.43$ & $2.50-16.3$ & $0.43-0.86$ & 2.21 \\
$T h / S c$ & $0.82-1.46$ & $0.84-20.5$ & $0.05-0.22$ & 0.79 \\
$T h / C o$ & $0.83-1.45$ & $0.67-19.4$ & $0.04-1.40$ & 0.63 \\
$\mathrm{La} / \mathrm{Co}$ & $2.07-3.68$ & $1.80-13.8$ & $0.14-0.38$ & 1.76 \\
\hline
\end{tabular}

Table 8. Trace element ratios of the Neogene mudrocks

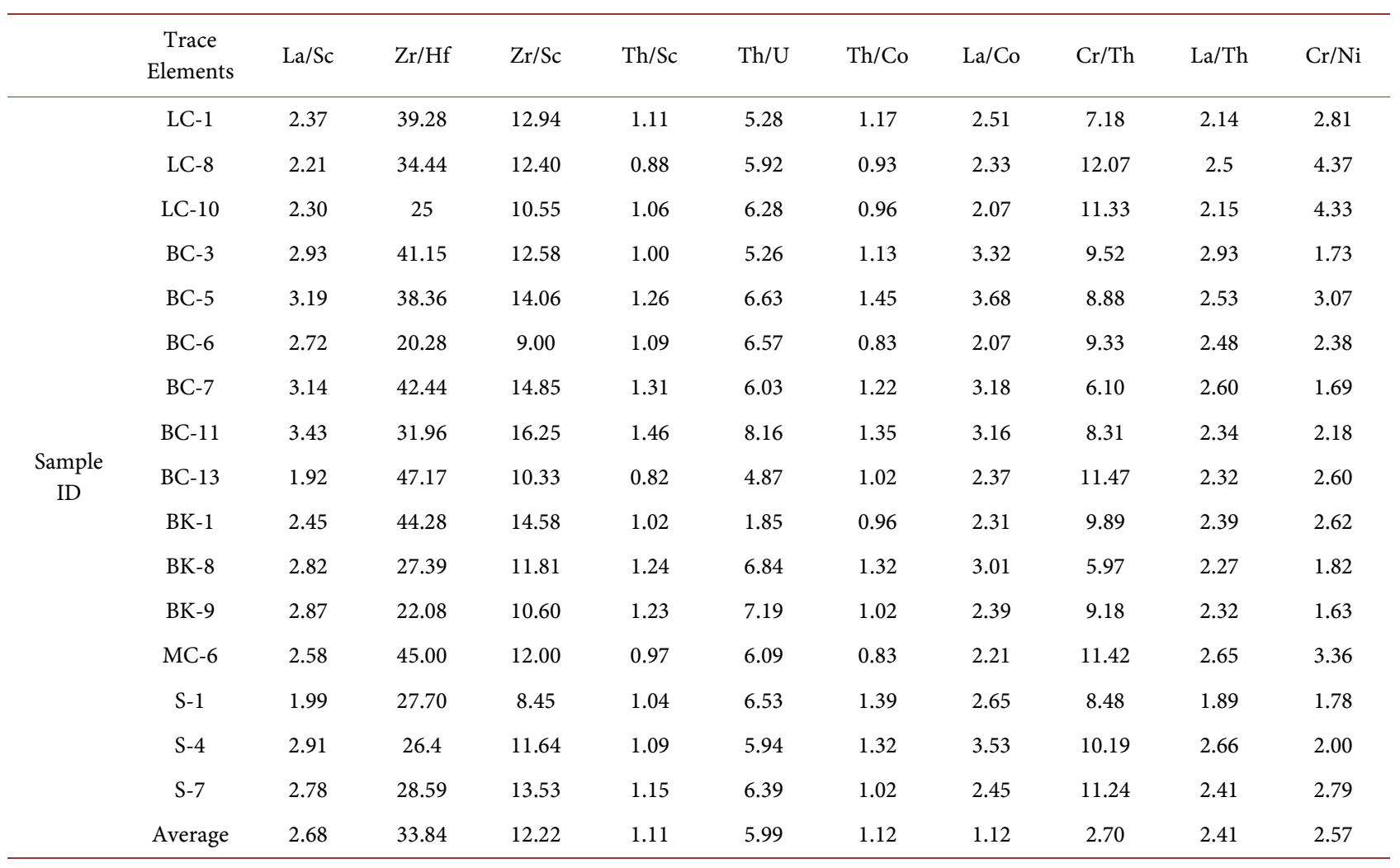


On Sc-Th scatter diagram (Figure 4), most of the Neogene mudrocks plot in the field of felsic composition although few samples inhabit a field that bears the characteristics of intermediate composition. The origin from the Indo-Burman Ranges could also be probable in part, e.g. Uddin and Lundberg (1998) [24] showed the evidence that ophiolitic detritus could be resulted from the suture zone of the Indo-Burman Ranges.

Generally, there are Four groups of provenance: mafic and less-intermediate igneous (P1), intermediate igneous (P2), felsic igneous (P3), and quartzose sediments of mature continental provenance (P4). To conclude provenance, Roser and Korsch (1988) [4] proposed unstandardized discriminant function scores of the samples (F1 and F2) for major elements [4] were schemed following the boundaries flanked by fields (P1-P4) (Figure 5).

Following equation used for discriminant functions:

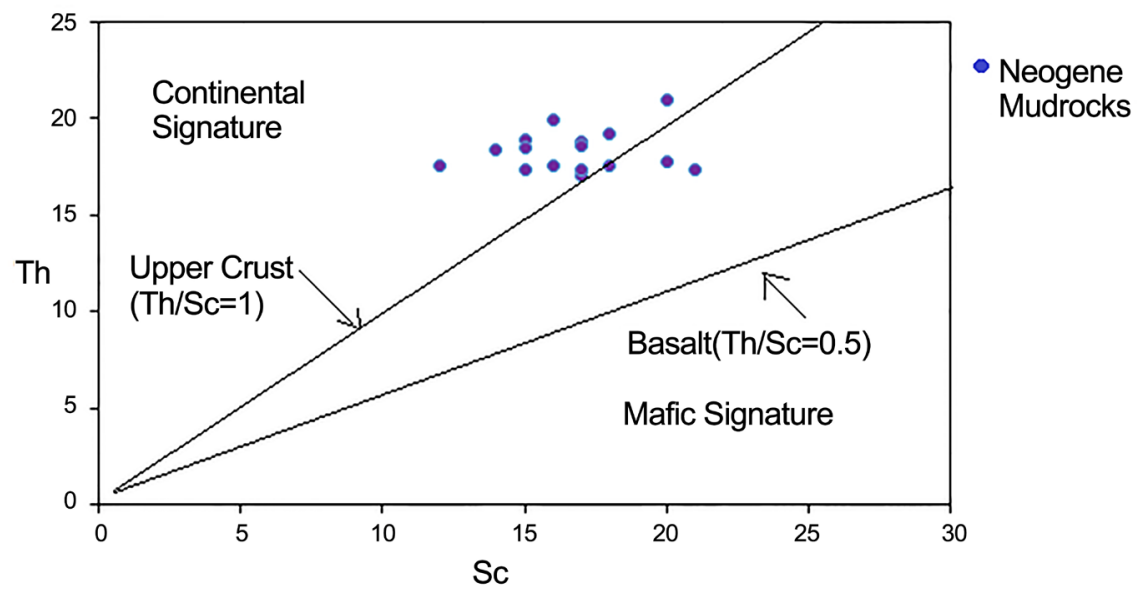

Figure 4. Sc-Th plot for Neogene mudrocks of the Sitakund anticline.

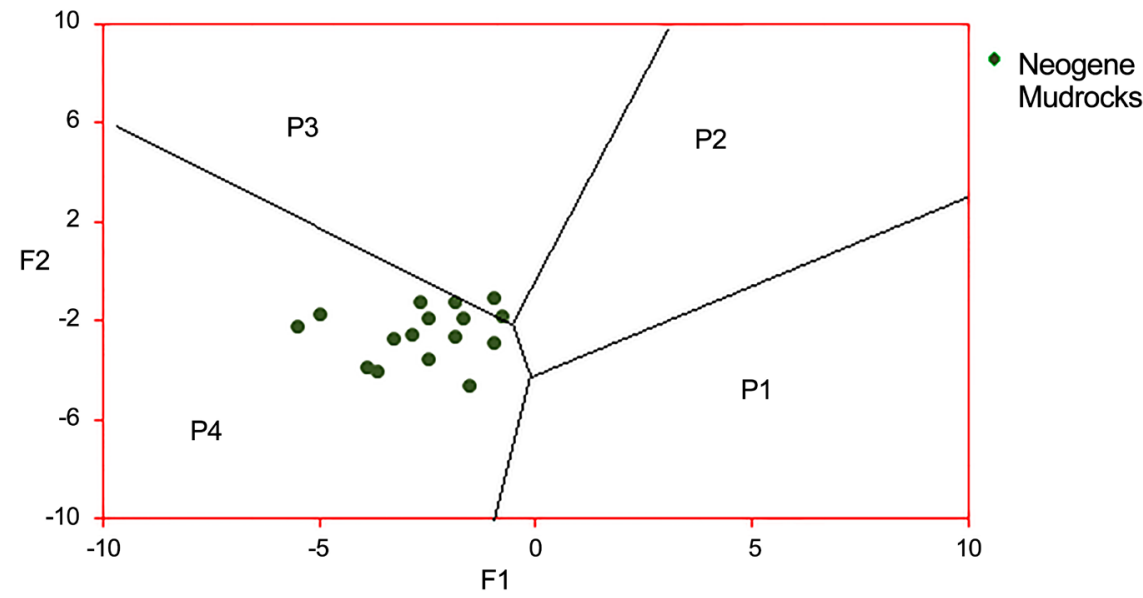

Figure 5. Discriminant functions F1 and F2 are plotted for the Neogene mudrocks of Sitakund anticline. Roser and Korsch (1988) [4] divided the boundary values of Provenance fields. P1 = mafic and lesser intermediate igneous provenance; P2 = intermediate igneous provenance; $\mathrm{P} 3$ = felsic igneous provenance and $\mathrm{P} 4=$ recycled-mature polycyclic quartzose detritus. 


$$
\begin{aligned}
& \text { Discriminant function } 1=\left(-1.773 \cdot \mathrm{TiO}_{2}\right)+\left(0.607 \cdot \mathrm{Al}_{2} \mathrm{O}_{3}\right)+\left(0.760 \cdot \mathrm{Fe}_{2} \mathrm{O}_{3}\right)+ \\
& (-1.500 . \mathrm{MgO})+(0.616 . \mathrm{CaO})+\left(0.509 . \mathrm{Na}_{2} \mathrm{O}\right)+\left(-1.224 . \mathrm{K}_{2} \mathrm{O}\right)+(-9.090) \text {; } \\
& \text { Discriminant function } 2=\left(0.445 . \mathrm{TiO}_{2}\right)+\left(0.070 . \mathrm{Al}_{2} \mathrm{O}_{3}\right)+\left(-0.250 \cdot \mathrm{Fe}_{2} \mathrm{O}_{3}\right)+ \\
& (-1.142 \cdot \mathrm{MgO})+(0.438 \cdot \mathrm{CaO})+\left(1.475 \cdot \mathrm{Na}_{2} \mathrm{O}\right)+\left(-1.426 \cdot \mathrm{K}_{2} \mathrm{O}\right)+(-6.861) \text {. }
\end{aligned}
$$

(P1 first-cycle basaltic and minor andesitic detritus, $\mathrm{P} 2$ dominantly andesitic materials, P3 acid plutonic and volcanic detritus, and P4 mature polycyclic quartzose detritus) Most of the Mudrocks from Sitakund anticline are located within the $\mathrm{P} 4$ field, which signifies a recycled mature polycyclic quartzose detritus.

The sediment repository preserved in the Bengal Basin is predominantly a huge delta complex fed by the coalesced Ganges and Brahmaputra rivers. It preserves (16 - $22 \mathrm{~km})$ thick sequence of Cenozoic sediments [23] [44] [45] [46] from oldest to youngest, the Sylhet, Kopili, Bhuban, Bokabil, Tipam and DupiTila Formations, which show facies evolution from marine through deltaic to fluvial environments. The Cenozoic sedimentary succession of Bangladesh provides a storehouse of Himalayan erosion [47]. The enormous stack of inter-bedded sandstones and mudrocks could have been consequent from rapid erosion of quick rising Himalayas and Indo-Burman Ranges. The occurrence of granitic plutons, Mesozoic flysch deposits, ophiolite rocks, and Tertiary molasse sediments are usual in the Eastern Himalayan structural belt [48]. In the Indo-Burman Ranges, thick Eocene to Oligocene turbidite successions and Upper Miocene to Pleistocene molasses sediments [24] are the important rocks successions. In Hatia Trough and Chittagong Hill Tracts, the Neogene facies are exposed. Although the Hatia Trough currently remains a site of sediment deposition, the Chittagong Hill Tracts consist of sediments deposited in the Bengal Basin, and subsequently uplifted and incorporated into the accretionary prism during subduction of the Indian oceanic plate beneath the Burma platelet to the east [45]. The relative contributions of huge pile of sediments to the Bengal basin from the Himalaya, Burman margin and Indian craton and Shillong Plateau, are disputed [1] [46] [49] [50] [51]. The low temperature Ar-Ar ages of detrital white mica from the Neogene sandstones of Surma Group are diagnostic of the youngest cooling events which can be correlated with early cooling ages from High Himalayan Crystalline rocks [52]. On the basis of sand petrography and lithofacies maps, it is evident that the Miocene sediments were transported from the immediate east, comprising the Indo-Burman Ranges too and produce a vivid record of unroofing of the eastern Himalaya/Indo-Burman Ranges [1] [24]. Most probably Himalayan terrain, particularly Eastern Himalaya could be documented as the principal source area of the Neogene mudrocks from Sitakund anticline. Theflysch successions which is comprised of Recycled sediment material of the Indo-Burman Ranges could also be amalgamated with the sediments of Himalayan origin within the deltaic sediment suits.

\subsection{Weathering}

Highly weathered granitic gneissic terrain and/or pre-existing sedimentary terrain could be the source of sediments [4]. Weathering that occurs in the hinter- 
land is estimated as CIA. To determine the weathering history of sedimentary rocks, Nesbitt and Young (1982) [10] recommended the CIA value (Chemical Index of Alteration) by means of molecular proportion of some bulk elements. Progressive alteration of plagioclase and potassium feldspars to clay minerals examined by chemical index of alteration (CIA). Average concentrations of alkali and alkaline earth elements varies in the course of weathering with chemical alteration [9] [10].

The following equation was used to determine CIA value:

$$
\mathrm{CIA}=\left[\mathrm{Al}_{2} \mathrm{O}_{3} /\left(\mathrm{Al}_{2} \mathrm{O}_{3}+\mathrm{CaO} *+\mathrm{Na}_{2} \mathrm{O}+\mathrm{K}_{2} \mathrm{O}\right)\right] * 100
$$

Where $\mathrm{CaO}^{*}$ stands for the amount of $\mathrm{CaO}$ united in the silicate phases.

$\left(\mathrm{CaO}^{*}=\mathrm{CaO}-10 / 3\right)[8]$.

Lack of weathering in samples represented by low CIA values (50 or less) whereas high values $(76$ - 100) specify a greatly chemically weathered source region [10] [53]. CIA values for the Neogene mudrocks vary from 67.81 to 77.57 with an average 74.41 indicating significant weathering at the source areas. The obtained average CIA value ( 75) is higher than that of the CIA value (50) of upper continental crust. The CIA values are also plotted in $\mathrm{Al}_{2} \mathrm{O}_{3}\left(\mathrm{CaO}^{*}+\mathrm{Na}_{2} \mathrm{O}\right)$ - $\mathrm{K}_{2} \mathrm{O}$ (A-CN-K) diagram (Figure 6). In the A-CN-K diagram, values of the samples occupy near the $\mathrm{Al}_{2} \mathrm{O}_{3}$ portion, far from the line linking plagioclase and $\mathrm{K}$-feldspar. The acquired CIA values are symptomatic of the weathered nature of some of the minerals incorporated in Mudrocks. The negative correlation between CIA and $\mathrm{K}_{2} \mathrm{O} / \mathrm{Al}_{2} \mathrm{O}_{3}$ recommends that clay fraction generally consists of $\mathrm{K}$-bearing minerals. Intensely weathered soils tends to be enriched in $\mathrm{TiO}_{2}$ due to its low solubility. However, our analysis shows that $\mathrm{TiO}_{2}$ concentration declines with rising CIA values. The observation advocates that these sediments derived from a $\mathrm{TiO}_{2}$ dwindling felsic source rocks [54].
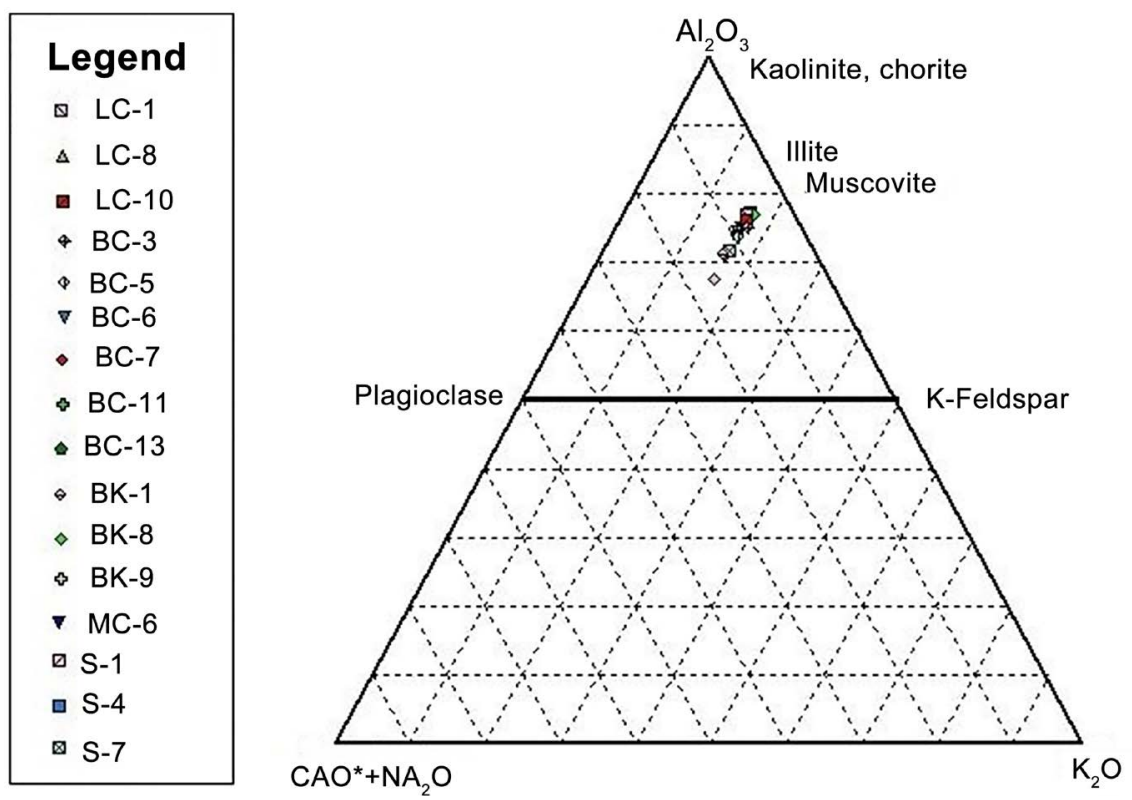

Figure 6. Ternary diagram (CIA) of Neogene mudrocks (After Nesbitt and Young 1982) [10]. 
From the relation, $\mathrm{Na}_{2} \mathrm{O} / \mathrm{K}_{2} \mathrm{O}<1$, the mudrocks seem to be mature (Table 9). The Th/U ratio differs from 3.5 to 4.0 for most upper crust rocks [8]. Enrichment of $U$ is commonly found in anoxic sediments. During weathering and sedimentary recycling under oxidizing conditions, insoluble $\mathrm{U}^{4+}$ ions are converted into soluble $\mathrm{U}^{6+}$ ions. Higher $\mathrm{Th} / \mathrm{U}$ values are indicative of dissolution and loss of $U$ during sedimentation [8] [11]. Low $\mathrm{Th} / \mathrm{U}$ ratios indicate the enrichment of $U$ in the sediments. In sedimentary rocks, Th scatters as a trace element in heavy minerals (e.g. zircon and monazite). $U$ is not copious in coarse-grained inorganic sedimentary rocks (e.g. quartzite and arkose); the range generally is from 0.5 to $1.5 \mathrm{ppm}$ but can increase with increasing clay minerals [55]. The Th/U ratio is a significant index for checking kaolinite content, which upsurges with elevated $\mathrm{Th} / \mathrm{U}$ values. In sedimentary rocks, $\mathrm{Th} / \mathrm{U}$ values greater than 4.0 may specify intense weathering in source areas or sediment recycling. The $\mathrm{Th} / \mathrm{U}$ ratios in the Neogene mudrocks range from 4.87 to 8.16 , with an average of 5.99 , indicating the derivation of these sediments from the recycling of the crust. (Figure 7) shows a typical distribution similar to the average values of fine grained sedimentary rocks testified by Taylor and McLennan (1985) [8] and follows the normal weathering trend [11].

It is most likely that the sources for the Neogene mudrocks were recycled sediments and have undergone significant weathering. Mudrocks containing plagioclase ( 9\%) [52] may indicate insignificant chemical weathering during sedimentation within the basin [56], however the CIA values of mudrocks are indicative of the significant weathering in their source. The calculated CIA values for the Neogene mudrocks are very much similar to the CIA values of the Yamuna River System sediments in the Himalaya ( 51 to 69 ; average 60) [57].

Table 9. Showing the ratio of major oxides.

\begin{tabular}{|c|c|c|c|c|c|c|c|}
\hline \multicolumn{2}{|c|}{ Major Elements Ratio } & \multirow{2}{*}{$\frac{\mathrm{K}_{2} \mathrm{O} / \mathrm{Na}_{2} \mathrm{O}}{3.64}$} & \multirow{2}{*}{$\begin{array}{c}\mathrm{Na}_{2} \mathrm{O} / \mathrm{K}_{2} \mathrm{O} \\
0.27\end{array}$} & \multirow{2}{*}{$\begin{array}{c}\mathrm{Fe}_{2} \mathrm{O}_{3}+\mathrm{MgO} \\
10.91\end{array}$} & \multirow{2}{*}{$\begin{array}{c}\mathrm{SiO}_{2} / \mathrm{Al}_{2} \mathrm{O}_{3} \\
3.36\end{array}$} & \multirow{2}{*}{$\begin{array}{c}\mathrm{Al}_{2} \mathrm{O}_{3} / \mathrm{TiO}_{2} \\
18.23\end{array}$} & \multirow{2}{*}{$\begin{array}{c}\mathrm{K}_{2} \mathrm{O} / \mathrm{Al}_{2} \mathrm{O}_{3} \\
0.21\end{array}$} \\
\hline \multirow{17}{*}{$\begin{array}{c}\text { Sample } \\
\text { ID }\end{array}$} & LC-1 & & & & & & \\
\hline & LC-8 & 5.13 & 0.19 & 10.81 & 3.24 & 17.79 & 0.23 \\
\hline & LC-10 & 5.81 & 0.17 & 11.17 & 2.87 & 22.11 & 0.22 \\
\hline & BC-3 & 4.76 & 0.20 & 11.75 & 3.13 & 17.62 & 0.21 \\
\hline & BC-5 & 4.01 & 0.25 & 12.33 & 2.91 & 18.21 & 0.21 \\
\hline & BC-6 & 3.56 & 0.28 & 12.08 & 2.97 & 22.36 & 0.21 \\
\hline & BC-7 & 3.87 & 0.25 & 11.91 & 3.09 & 19.41 & 0.22 \\
\hline & BC-11 & 3.53 & 0.28 & 10.59 & 3.67 & 16.84 & 0.24 \\
\hline & BC-13 & 3.75 & 0.26 & 11.69 & 3.13 & 21.23 & 0.21 \\
\hline & BK-1 & 3.37 & 0.29 & 11.73 & 3.17 & 18.34 & 0.21 \\
\hline & BK-8 & 4.49 & 0.22 & 13.10 & 2.74 & 19.50 & 0.21 \\
\hline & BK-9 & 4.30 & 0.23 & 12.32 & 2.80 & 20.37 & 0.21 \\
\hline & MC-6 & 3.95 & 0.25 & 11.05 & 3.56 & 17.66 & 0.23 \\
\hline & S-1 & 5.40 & 0.18 & 10.97 & 3.08 & 19.67 & 0.22 \\
\hline & S-4 & 4.36 & 0.22 & 11.59 & 2.96 & 19.34 & 0.23 \\
\hline & S-7 & 3.89 & 0.25 & 11.46 & 3.03 & 18.20 & 0.23 \\
\hline & Average & 4.24 & 0.24 & 11.59 & 3.11 & 19.18 & 0.22 \\
\hline
\end{tabular}




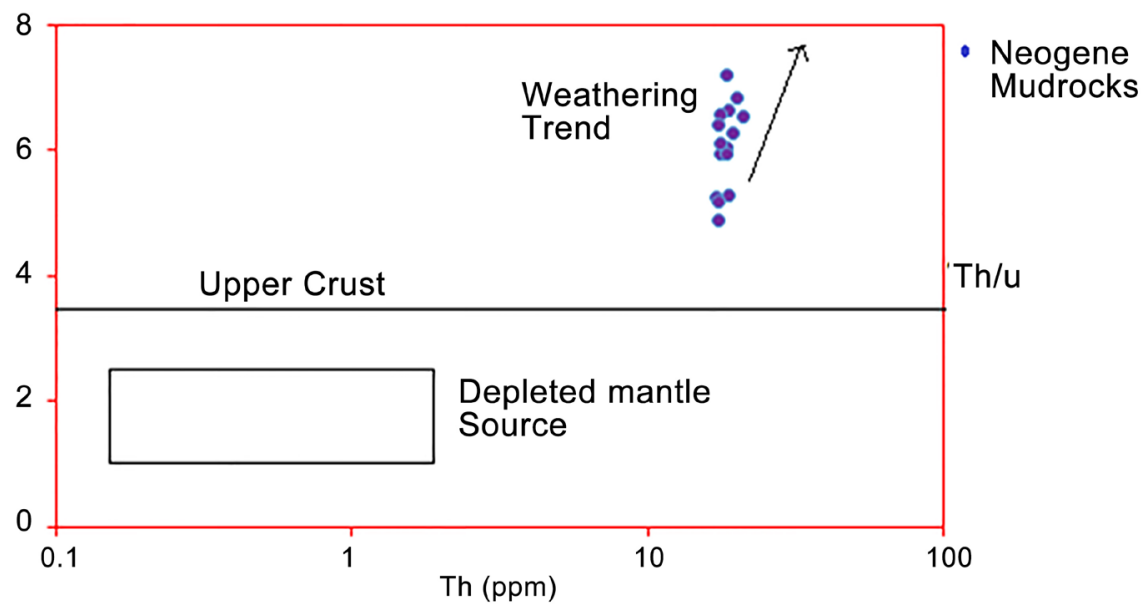

Figure 7. Plots of Th/U versus Th (after McLennan et al., 1993) [11].

\subsection{Tectonic Settings}

Trace elements and Major are crucial pointers for deducing tectonic setting. Bhatia (1985) [2] proposed that immobile trace elements (e.g. Zr, La, Nb, Th, Y, Sc) in mudrocks reserve the signs of tectonic setting and source rocks. He distinguished four major tectonic provenances (Oceanic island arc, continental island arc, active continental margin and passive margin) based on the Th, $\mathrm{U}, \mathrm{Nb}$, $\mathrm{La}, \mathrm{Cr}$, Ni concentrations and the ratio of $\mathrm{Th} / \mathrm{U}$ and $\mathrm{La} / \mathrm{Sc}$. Based on Bhatia's (1985) [2] idea, the trace elements of the samples recommend diverse tectonic setting varies from continental island arc to active continental margin to passive margin. The ratio of $\mathrm{La} / \mathrm{Sc}$ and content of $\mathrm{La}$ and $\mathrm{Nb}$ concentrations can be roughly matched with the contents of an active margin setting. Definite trace elements connecting to tectonic settings of Bhatia (1985) [2] were not conclusive for all four tectonic settings proved by McCann (1991) [60]. In Accordance with the idea of Bhatia (1985) [2], the active and passive continental margin $\mathrm{Mu}$ drocks are discriminated from other mudrocks by their significantly greater Nband Th. The active continental and passive margin Mudrocks are alike in most immobile trace elements, and can be differentiated from each other by higher $\mathrm{Ni}$ and $\mathrm{Cr}$ copiousness for the passive margin setting.

The increase in the $\mathrm{Cr}$ and $\mathrm{Ni}$ abundance for passive margin mudrocks is due to the enrichment and adsorption of these elements with the increased phyllosilicate content. The passive-margin comprised Atlantic-type rifted continental margins developed along the edges of the continent, remnant, ocean basins adjacent to collision orogens, and inactive or extinct convergent margins. Intra- cratonic and rift-bounded grabens (e.g. the Benue trough) were formed on a thick continental crust which are included in the passive-margin type tectonic setting. La-Th-Sc, Th-Sc-Zr/10, and Th-Co-Zr/10 are important ternary plots for determining tectonic setting although a La-Th-Sc plot cannot discriminate between active and passive continental margins; Th-Co- $\mathrm{Zr} / 10$ and $\mathrm{Th}-\mathrm{Sc}-\mathrm{Zr} / 10$ can differentiate these settings (Figure 8). These ternary 
plots can generally discriminate between the following tectonic settings: oceanic island $\operatorname{arc}(\mathrm{A})$, continental island $\operatorname{arc}(\mathrm{B})$, active continental margin (C), and passive margin (D) [5] [7]. The Th-Co-Zr/10 and Th-Sc-Zr/10 diagrams conclude that the analyzed mudrocks be owned by an active continental margin tectonic setting with high $\mathrm{Zr} / \mathrm{Th}$ ratios. Another discrimination diagram was proposed by Roser and Korsch (1986) [3], using $\mathrm{K}_{2} \mathrm{O} / \mathrm{Na}_{2} \mathrm{O}$ against $\mathrm{SiO}_{2}$. Intermediate values of $\mathrm{K}_{2} \mathrm{O} / \mathrm{Na}_{2} \mathrm{O}$ and $\mathrm{SiO}_{2}$ indicate a change from $\mathrm{PM}, \mathrm{ARC}$ to ACM. Intermediate $\mathrm{K}_{2} \mathrm{O} / \mathrm{Na}_{2} \mathrm{O}$ and $\mathrm{SiO}_{2}$ values indicate active continental margin tectonic environment of deposition for the analyzed Neogene mudrocks (Figure 9).

\begin{tabular}{|c|}
\hline Legend \\
\hline$\triangle \quad$ LC-1 \\
\hline$\triangle \quad$ LC-8 \\
\hline घ LC-10 \\
\hline - BC-3 \\
\hline $\begin{array}{l}* \text { BC-5 } \\
\approx \text { BC-6 }\end{array}$ \\
\hline - BC-7 \\
\hline BC-11 \\
\hline$\triangle B C-13$ \\
\hline - BK-1 \\
\hline$\diamond \mathrm{BK}-8$ \\
\hline \& BK-9 \\
\hline V MC-6 \\
\hline$S-1$ \\
\hline 口 S-4 \\
\hline S-7 \\
\hline
\end{tabular}

(a)

(b)

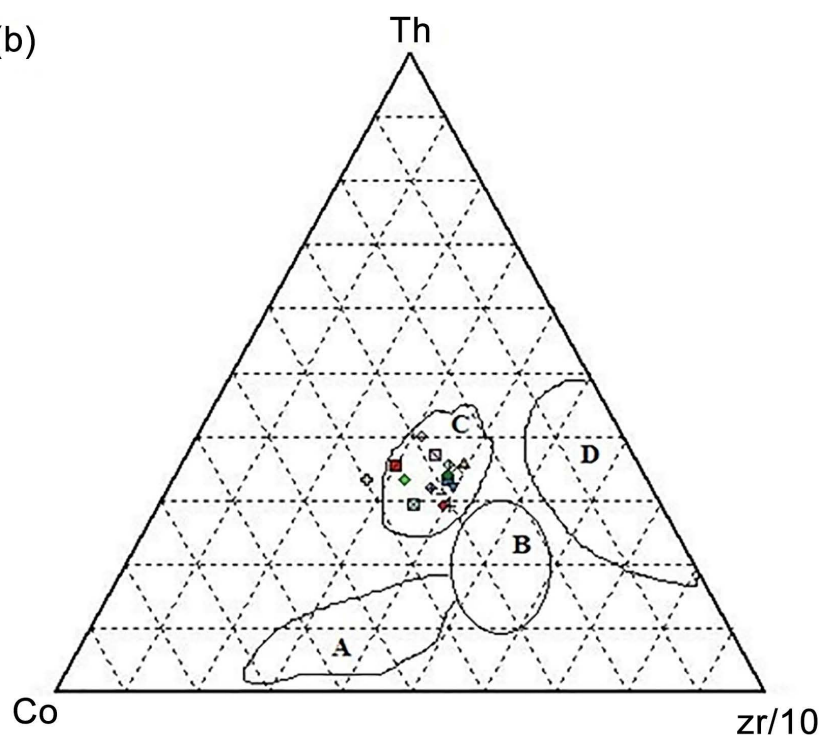

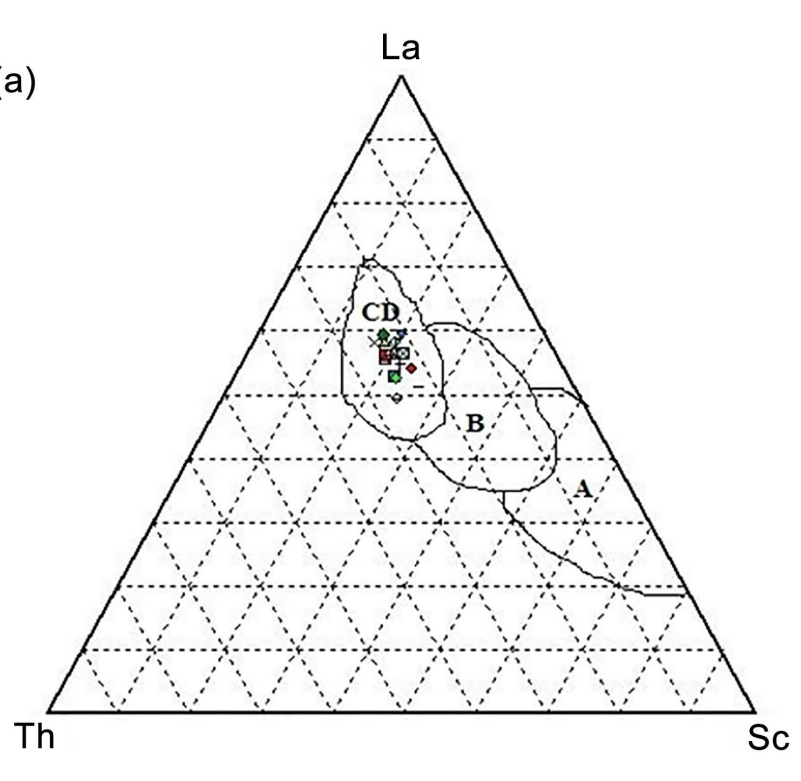

(c)

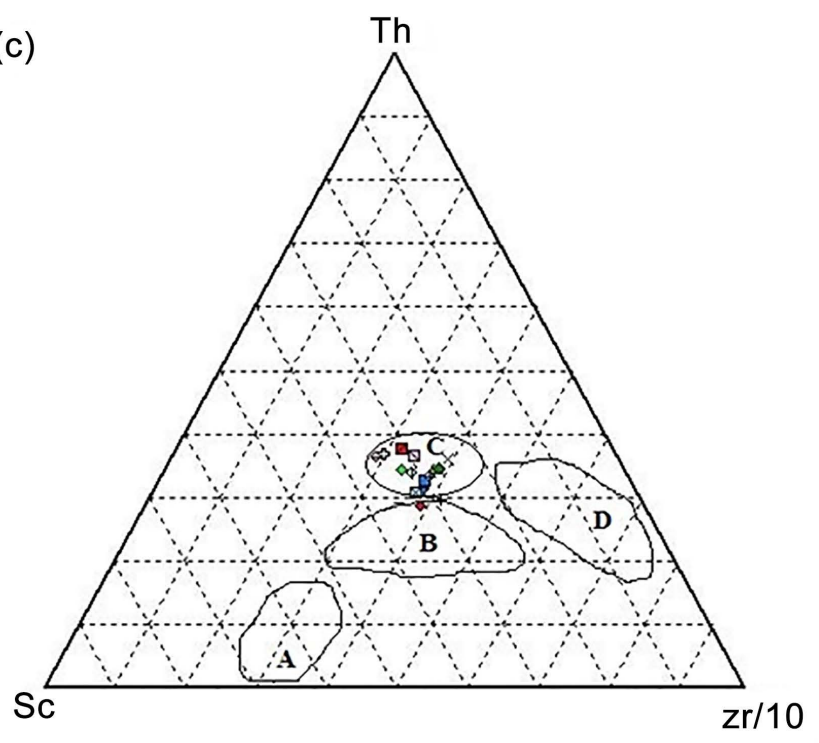

Figure 8. Trace element ternary plots for tectonic setting differentiation geochemically (After Bhatia and Crook) [7]. 


\subsection{Paleo-0xygenation Condition}

In this study, geochemical data were used to elucidate paleodepositional environments for Neogene mudrocks. Differing degrees of trace and REE element enrichment may reflect differences in depositional environment during accumulation. In the past, trace-element ratios such as $\mathrm{Ni} / \mathrm{Co}, \mathrm{V} / \mathrm{Cr}$ and $\mathrm{V} /(\mathrm{V}+\mathrm{Ni})$ have been used to evaluate the paleoredox conditions by various workers [16] [61] [62]. Dypvik (1984) [63] and Dill (1986) [64] have also used the Ni/Co ratio as a redox indicator. Jones and Manning (1994) suggested that $\mathrm{Ni} / \mathrm{Co}$ ratios $<5$ inferred oxic conditions, 5 - 7 dysoxic conditions and $>7$ suboxic to anoxic conditions. In the present study, Neogene mudrocks have moderate $\mathrm{Ni} / \mathrm{Co}$ ratio ranges from 2.51 to 6.75 indicating poor oxic to dysoxic condition. Vanadium, which is generally found in sediments deposited in reducing environments, may be bound to organic matter by the incorporation of V4+ into porphyrins [62]. V also may occur when adsorbed onto clay minerals, an association that probably results following its burial [65].

Cr is thought to be associated only with the detrital faction (Dill 1986) [64] and is not influenced by redox conditions, thus high $\mathrm{V} / \mathrm{Cr}$ values $(>2)$ are thought to indicate anoxic conditions. According to Jones and Manning 1994 [16], $\mathrm{V} / \mathrm{Cr}$ ratios <2 infer oxic conditions, 2 - 4.25 indicate dysoxic conditions and $>4.25$ infer suboxic to anoxic conditions; in addition, $\mathrm{V} /(\mathrm{V}+\mathrm{Ni})$ ratios greater than 0.84 suggest euxinic conditions, $0.54-0.82$ represent anoxic conditions and $0.46-0.60$ represent dysoxic conditions. In the present study, the $\mathrm{V} / \mathrm{Cr}$ ratios of all samples (Neogene mudrocks) varies between 0.45 and 1.00, which imply that these Mudrocks were deposited in an oxic depositional environment.

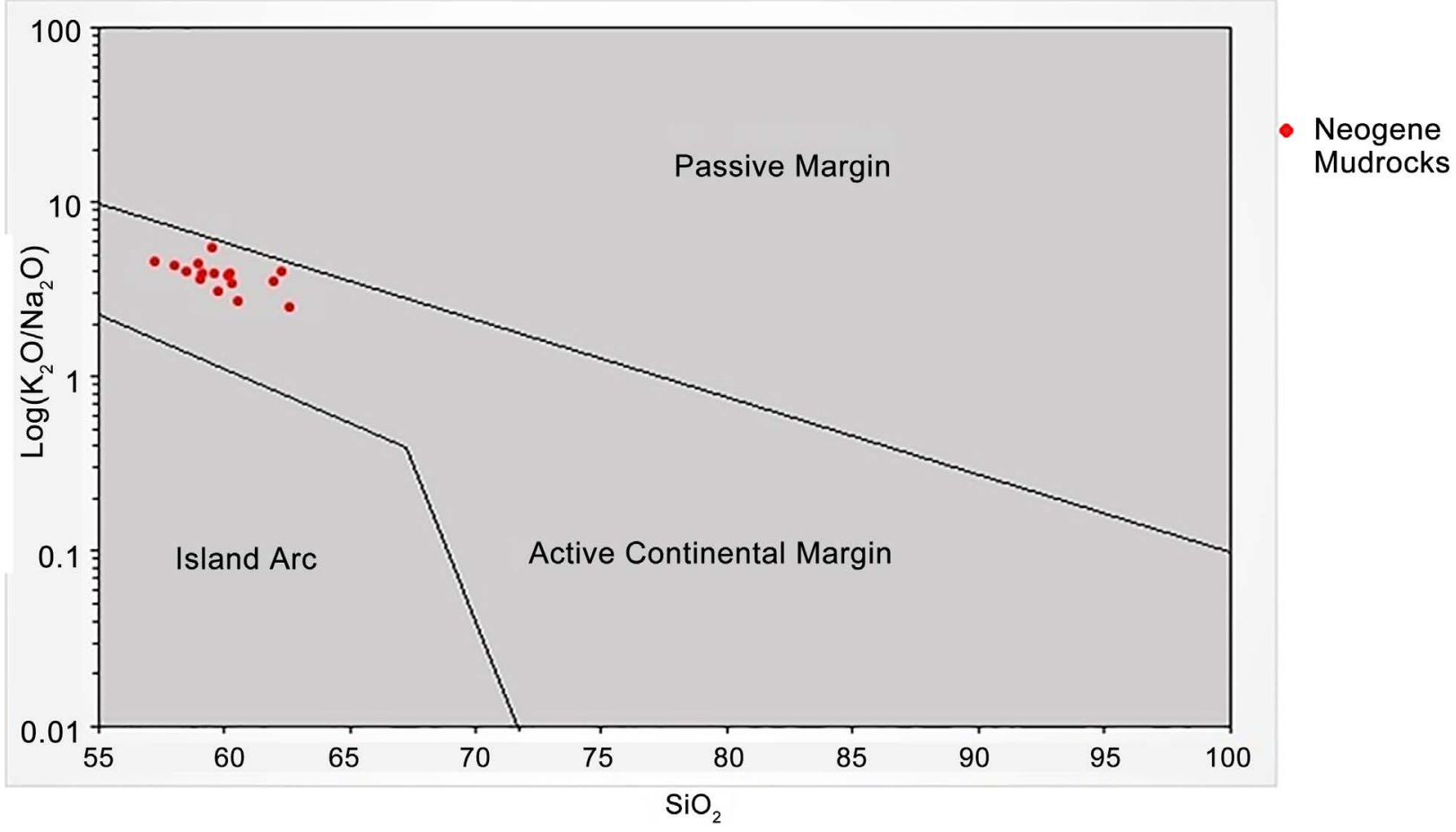

Figure 9. Tectonic discrimination diagram for Neogene mudrocks of the Sitakund anticline. Boundaries are after Roser and Korsch (1986) [3]. 
$\mathrm{Cu} / \mathrm{Zn}$ and $(\mathrm{Cu}+\mathrm{Mo}) / \mathrm{Zn}$ ratios have been put forward by Hallberg (1976) [66] as redox parameters. According to Hallberg (1976) [66], high Cu/Zn ratios indicate reducing depositional conditions, while low $\mathrm{Cu} / \mathrm{Zn}$ ratios suggest oxidizing conditions; he showed that high values should indicate more reducing conditions in the depositional basins than lower values, which may indicate more oxidizing conditions. Thus, the low $\mathrm{Cu} / \mathrm{Zn}$ ratios for Neogene mudrocks ( $\sim 46$ 0.98), respectively (Table 10) indicate that the Mudrocks were deposited under oxidizing conditions. The U/Th ratio may be used as a redox indicator with $\mathrm{U} / \mathrm{Th}$ ratio being higher in organic-rich mudstones [16].

Low contents of $U$ are generally found in sediments deposited in oxygenated conditions in marine environment, whereas high $U$ contents are found in sediments from the oxygen minimum zone [61] [67] thus, the U/Th ratio may be used as a redox indicator [16]. U/Th ratios below 1.25 suggest oxic conditions of deposition, whereas values above 1.25 indicate suboxic and anoxic conditions [17]. In this study, the samples have low U/Th ratios $(\sim 0.12-0.53)$ indicating that samples were deposited in an oxic environment. It is suggested that thresholds established for paleoredox indicators in these studies should not be applied strictly, but that relative differences in these indicators collectively can infer variations in the degree of anoxia.

Table 10. Different elemental ratio important for paleo-oxygenation environment.

\begin{tabular}{|c|c|c|c|c|c|c|c|}
\hline \multicolumn{2}{|c|}{ Ratios of Trace elements } & \multirow{2}{*}{$\frac{\mathrm{Cu} / \mathrm{Zn}}{0.66}$} & \multirow{2}{*}{$\frac{(\mathrm{Cu}+\mathrm{Mo}) / \mathrm{Zn}}{0.74}$} & \multirow{2}{*}{$\begin{array}{c}\mathrm{Ni} / \mathrm{Co} \\
2.99\end{array}$} & \multirow{2}{*}{$\begin{array}{l}\mathrm{U} / \mathrm{Th} \\
0.18\end{array}$} & \multirow{2}{*}{$\begin{array}{l}\mathrm{V} / \mathrm{Cr} \\
0.82\end{array}$} & \multirow{2}{*}{$\frac{\mathrm{V} /(\mathrm{V}+\mathrm{Ni})}{0.70}$} \\
\hline & LC-1 & & & & & & \\
\hline & LC_8 & 0.56 & 0.62 & 2.57 & 0.16 & 0.47 & 0.67 \\
\hline & LC-10 & 0.57 & 0.64 & 2.51 & 0.15 & 0.50 & 0.68 \\
\hline & BC-3 & 0.64 & 0.73 & 6.21 & 0.19 & 0.59 & 0.50 \\
\hline & BC-5 & 0.52 & 0.60 & 4.20 & 0.15 & 0.58 & 0.64 \\
\hline & BC-6 & 0.56 & 0.65 & 3.27 & 0.15 & 0.60 & 0.59 \\
\hline & BC-7 & 0.98 & 1.11 & 4.41 & 0.16 & 0.70 & 0.54 \\
\hline \multirow{9}{*}{$\begin{array}{l}\text { Sample } \\
\text { ID }\end{array}$} & BC-11 & 0.65 & 0.73 & 5.13 & 0.12 & 0.61 & 0.57 \\
\hline & BC-13 & 0.50 & 0.56 & 4.49 & 0.20 & 0.46 & 0.54 \\
\hline & BK-1 & 0.46 & 0.54 & 3.63 & 0.53 & 0.50 & 0.56 \\
\hline & BK-8 & 0.63 & 0.69 & 4.34 & 0.14 & 1.00 & 0.64 \\
\hline & BK-9 & 0.69 & 0.77 & 5.77 & 0.13 & 0.78 & 0.56 \\
\hline & MC-6 & 0.55 & 0.62 & 2.83 & 0.16 & 0.45 & 0.60 \\
\hline & S-1 & 0.46 & 0.52 & 6.66 & 0.15 & 0.68 & 0.54 \\
\hline & S-4 & 0.68 & 0.74 & 6.75 & 0.16 & 0.52 & 0.50 \\
\hline & S-7 & 0.48 & 0.54 & 4.1 & 0.15 & 0.50 & 0.58 \\
\hline
\end{tabular}

\section{Conclusion}

There is a substantial variation of major, trace and rare earth elements in Neogene mudrocks. $\mathrm{SiO}_{2}$ content of the Neogene mudrocks was shown high (varying from $58.10 \%$ to $62.60 \%$, average $59.90 \%$ ). $\mathrm{The}^{\mathrm{TiO}_{2}}$ concentration varies from 0.88 to 
1.10 wt. $\% ; \mathrm{F}_{2} \mathrm{O}_{3}$ content ranges from 7.74 to 9.67 wt.\% and the $\mathrm{Al}_{2} \mathrm{O}_{3}$ content from 18.60 to 20.89 wt.\%. Mudrocks collected from Sitakund anticline were studied for geochemistry in to recognize the strength of provenance, weathering and tectonic setting. The CIA values for the Neogene mudrocks vary from 67.81 to 77.57 with an average 74.41 indicating significant weathering at the source areas. Neogene sediments experienced significant weathering and recycling processes in order to orogenic activities, and that these sediments were finally deposited in a subsiding geosynclinal basin. The discrimination diagrams (Bhatia, 1983) [5] for distinguishing the tectonic setting suggest the active continental margin and preserve the signatures of recycled provenance field that have undergone significant degrees of weathering. Discriminant-function multi-dimensional diagram showed that the mudrocks of the Sitakund anticline were originated from a continental collision zone, which is more or less similar to the Bengal Basin geology. Our assumption is that these mudrocks were derived primarily from felsic continental sources. These results help unveil the complex tectonic history of Bengal Basin. The sources have identified as recycled detritus; the source regions such as the most of the Himalayan rocks are made of recycled material and indeed it could be a governing supplier. Recycled sediment material from the flysch sequences of the Indo-Burma Ranges might also be coagulated with the Himalayan origin sediments within the deltaic sediment suits.

\section{Acknowledgements}

The laboratory support of USAID Peer Science Grant and Institute of Mining, Mineralogy and Metallurgy, BCSIR to carry out this research work is acknowledged appreciatively. The facilities provided by the Department of Geology, University of Dhaka are gratefully acknowledged. Valuable comments and suggestions from anonymous reviewers are highly acknowledged.

\section{References}

[1] Uddin, A. and Lundberg, N. (1999) A Paleo-Brahmaputra? Subsurface Lithofacies Analysis of Miocene Deltaic Sediments in the Himalayan-Bengal System, Bangladesh. Sedimentary Geology, 123, 239-254.

https://doi.org/10.1016/S0037-0738(98)00134-1

[2] Bhatia, M.R. (1985) Composition and Classification of Paleozoic Flyschmudrocks of Eastern Australia: Implications in Provenance and Tectonic Setting Interpretation. Sedimentary Geology, 41, 249-268. https://doi.org/10.1016/0037-0738(84)90065-4

[3] Roser, B.P. and Korsch, R.J. (1986) Determination of Tectonic Setting of Sandstone-Mudstone Suites Using $\mathrm{SiO}_{2}$ Content and $\mathrm{K}_{2} \mathrm{O} / \mathrm{Na}_{2} \mathrm{O}$ Ratio. The Journal of Geology, 94, 635-650. https://doi.org/10.1086/629071

[4] Roser, B.P. and Korsch, R.J. (1988) Provenance Signatures of Sandstone-Mudstone Suites Determined Using Discriminant Function Analysis of Major-Element Data. Chemical Geology, 67, 119-139. https://doi.org/10.1016/0009-2541(88)90010-1

[5] Bhatia, M.R. (1983) Plate Tectonics and Geochemical Composition of Sandstones. The Journal of Geology, 91, 611-627. https://doi.org/10.1086/628815 
[6] McLennan, S.M., Taylor, S.R. and Eriksson, K.A. (1983) Geochemistry of Archeanshales from the Pilbara Supergroup, Western Australia. Geochimica et Cosmochimica Acta, 47, 1211-1222. https://doi.org/10.1016/0016-7037(83)90063-7

[7] Bhatia, M.R. and Crook, K.A.W. (1986) Trace Element Characteristics of Greywackes and Tectonic Setting Discrimination of Sedimentary Basin. Contributions to Mineralogy and Petrology, 92, 181-193. https://doi.org/10.1007/BF00375292

[8] McLennan, S.M., Hemming, S., McDaniel, D.K. and Hanson, G.N. (1993) Geochemical Approaches to Sedimentation, Provenance and Tectonics. Special Paper of the Geological Society of America, 284, 21-40.

[9] Nesbitt, H.W., Markovics, G. and Price, R.C. (1980) Chemical Processes Affecting Alkalines and Alkaline Earths during Continental Weathering. Geochimica et Cosmochimica Acta, 44, 1659-1666. https://doi.org/10.1016/0016-7037(80)90218-5

[10] Nesbitt, H.W. and Young, G.M. (1982) Early Proterozoic Climates and Plate Motions Inferred from Major Element Chemistry of Lutites. Nature, 299, 715-771.

[11] Taylor, S.R. and McLennan, S.M. (1985) The Continental Crust: Its Composition and Evolution. The Journal of Geology, 94.

[12] Dabard, M.P. (1990) Lower Brioverian Formations (Upper Proterozoic) of the Armorican Massif (France): Geodynamic Evolution of Source Areas Revealed by Sandstone Petrography and Geochemistry. Sedimentary Geology, 69, 45-58.

[13] Crichton, J.G. and Condie, K.C. (1993) Trace Elements as Source Indicators in Cratonic Sediments: A Case of Study from the Early Proterozoic Libby Creek Group, Southwestern Wyoming. The Journal of Geology, 101, 319-332. https://doi.org/10.1086/648226

[14] Verma, S.P. and Armstrong-Altrin, J.S. (2013) New Multi-Dimensional Diagrams for Tectonic Discrimination of Siliciclastic Sediments and Their Application to Precambrian Basins. Chemical Geology, 355, 117-133.

https://doi.org/10.1016/j.chemgeo.2013.07.014

[15] Calvert, S.E. and Pedersen, T.F. (1993) Geochemistry of Recent Oxic and Anoxic Marine Sediments: Implications for the Geological Record. Marine Geology, 113, 67-88. https://doi.org/10.1016/0025-3227(93)90150-T

[16] Jones, B. and Manning, D.C. (1994) Comparison of Geochemical Indices Used for the Interpretation of Paleoredox Conditions in Ancient Mudstones. Chemical Geology, 111, 111-129. https://doi.org/10.1016/0009-2541(94)90085-X

[17] Nath, B.N., Bau, M., Ramalingeswara Rao, B. and Rao, Ch.M. (1997) Trace and Rare Earth Elemental Variation in Arabian Sea Sediments through a Transect across the Oxygen Minimum Zone. Geochimica et Cosmochimica Acta, 61, 2375-2388.

[18] Cullers, R.L. (2000) The Geochemistry of Shales, Siltstones and Sandstones of Pennsylvanian-Permian age, Colorado, USA: Implications for Provenance and Metamorphic Studies. Lithos, 51, 181-203. https://doi.org/10.1016/S0024-4937(99)00063-8

[19] Armstrong-Altrin, J.S., Lee, Y.I., Verma, S.P. and Ramasamy, S. (2004) Geochemistry of Sandstones from the Upper Miocene Kudankulam Formation, Southern India: Implications for Provenance, Weathering, and Tectonic Setting. Journal of Sedimentary Research, 74, 285-297. https://doi.org/10.1306/082803740285

[20] Dobrzinski, N., Bahlburg, H., Strauss, H. and Zhang, Q.R. (2004) Geochemical Climate Proxies Applied to the Neoproterozoic Glacial Succession on the Yangtze Platform, South China. In: Jenkins, G., et al., Eds., The Extreme Proterozoic. Geology, Geochemistry and Climate, American Geophysical Union Monograph Series, 146, 13-32. 
[21] Alam, M., Alam, M.M., Curray, J.R., Chowdhury, M.L.R. and Gani, M.R. (2003) An Overview of the Sedimentary Geology of the Bengal Basin in Relation to the Regional Tectonic Framework and Basin-Fill History. Sedimentary Geology, 155, 179208. https://doi.org/10.1016/S0037-0738(02)00180-X

[22] Shamsuddin, A.H.M. and Abdullah, S.K.M. (1997) Geologic Evolution of the Bengal Basin and Its Implication in Hydrocarbon Exploration in Bangladesh. Indian Journal of Geology, 69, 93-121.

[23] Curray, J.R. and Moore, D.G. (1971) Growth of the Bengal Deep-Sea Fan and Denudation in the Himalayas. The Geological Society of America Bulletin, 82, 563572. https://doi.org/10.1130/0016-7606(1971)82[563:GOTBDF]2.0.CO;2

[24] Uddin, A. and Lundberg, N. (1998) Unroofing History of the Eastern Himalaya and the Indo-Burman Ranges: Heavy-Mineral Study of Cenozoic Sediments from the Bengal Basin, Bangladesh. Journal of Sedimentary Research, 68, 465.

https://doi.org/10.2110/jsr.68.465

[25] Akhter, S.H. (1979) Structure, Stratigraphy and Sedimentology of the Upper Tertiary Sediments of the Central Part of the Sitakund Hill Range, Chittagong, Bangladesh. Doctoral Dissertation, Geology Department, Dhaka University, Bangladesh.

[26] Goto, A. and Tatsumi, Y. (1994) Quantitative Analysis of Rock Samples by an X-Ray Fluorescence Spectrometer (I). The Rigaku Journal, 11, 40-59.

[27] Wedepohl, K.H. (1971) Environmental Influences on the Chemical Composition of Shales and Clays. Physics and Chemistry of the Earth, 8, 307-333.

https://doi.org/10.1016/0079-1946(71)90020-6

[28] Gromet, L.P., Dymek, R.F., Haskin, L.A. and Korotev, R.L. (1984) “The North American Shale Composite" Its Composition, Major and Trace Element Characteristics. Geochimica et Cosmochimica Acta, 48, 2469-248.

[29] Cox, R., Lowe, D.R. and Cullers, R.L. (1995) The Influence of Sediment Recycling and Basement Composition on Evolution of Mudrock Chemistry in the Southwestern United States. Geochimica et Cosmochimica Acta, 59, 2919-2940. https://doi.org/10.1016/0016-7037(95)00185-9

[30] Taylor, S.R., McLennan, S.M., Armstrong, R.L. and Tarney, J. (1981) The Composition and Evolution of the Continental Crust: Rare Earth Element Evidence from Sedimentary Rocks [and Discussion]. Philosophical Transactions of the Royal Society of London A: Mathematical, Physical and Engineering Sciences, 301, 381-399. https://doi.org/10.1098/rsta.1981.0119

[31] Condie, K.C. and Wronkiewicz, D.J. (1990) A New Look at the Archean-Proterozoic Boundary: Sediments and the Tectonic Setting Constraint. Developments in Precambrian Geology, 61-83. https://doi.org/10.1016/S0166-2635(08)70162-2

[32] Cullers, R.L. (1995) The Controls on the Major- and Trace-Element Evolution of Shales, Siltstones and Sandstones of Ordovician to Tertiary Are in the Wet Mountains Region, Colorado, U.S.A. Chemical Geology, 123, 107-131. https://doi.org/10.1016/0009-2541(95)00050-v

[33] Hayashi, K., Fujisawa, H., Holland, H. and Ohmoto, H. (1997) Geochemistry of $\sim 1.9$ Ga Sedimentary Rocks from Northeastern Labrador, Canada. Geochimica et Cosmochimica Acta, 61, 4115-4137. https://doi.org/10.1016/S0016-7037(97)00214-7

[34] Wrafter, J.P. and Graham, J.R. (1989) Ophiolitic Detritus in the Ordovician Sediments of South Mayo Ireland. Journal of the Geological Society(London), 146, 213215. https://doi.org/10.1144/gsigs.146.2.0213

[35] Garver, J.I., Royce, P.R. and Smick, T.A. (1996) Chromium and Nickel in Shale of the Taconic Foreland: A Case Study for the Provenance of Fine-Grained Sediments with an Ultramafic Source. Journal of Sedimentary Research, 100, 100-106. 
[36] France-Lanord, C., Derry, L. and Michard, A. (1993) Evolution of the Himalaya since Miocene Time: Isotopic and Sedimentologic Evidence from the Bengal Fan. Geological Society, London, Special Publications, 74, 603-621. https://doi.org/10.1144/gsl.sp.1993.074.01.40

[37] Nance, W.B. and Taylor, S.R. (1976) Rare Earth Element Patterns and Crustal Evolution-I. Australian Post-Archean Sedimentary Rocks. Geochimica et Cosmochimica Acta, 40, 1539-1551. https://doi.org/10.1016/0016-7037(76)90093-4

[38] Nance, W.B. and Taylor, S.R. (1977) Rare Earth Element Patterns and Crustal Evolution-II. Archean Sedimentary Rocks from Kalgoorlie, Australia. Geochimica et Cosmochimica Acta, 41, 225-231. https://doi.org/10.1016/0016-7037(77)90229-0

[39] Cullers, R.L. (1994) The Controls on the Major and Trace Element Variation of Shales, Siltstones, and Sandstones of Pennsylvanian-Permian Age from Uplifted Continental Blocks in Colorado to Platform Sediment in Kansas, USA. Geochimica et Cosmochimica Acta, 58, 4955-4972. https://doi.org/10.1016/0016-7037(94)90224-0

[40] Wronkiewicz, D.J. and Condie, K.C. (1990) Geochemistry and Mineralogy of Sediments from the Ventersdorp and Transvaal Supergroups, South Africa: Cratonic Evolution during the Early Proterozoic. Geochimica et Cosmochimica Acta, 54, 343-354.

[41] Cullers, R.L., Basu, A. and Suttner, L.J. (1988) Geochemical Signature of Provenance in Sand-Size Material in Soils and Stream Sediments near the Tobacco Root Batholith, Montana, U.S.A. Chemical Geology, 70, 335-348. https://doi.org/10.1016/0009-2541(88)90123-4

[42] Feng, R. and Kerrich, R. (1990) Geochemistry of Fine-Grained Clastic Sediments in the Archean Abitibi Greenstones Belt, Canada: Implications for Provenance and Tectonic Setting. Geochimica et Cosmochimica Acta, 54, 1061-1081. https://doi.org/10.1016/0016-7037(90)90439-r

[43] Weaver, C.E. (1958) Geologic Interpretation of Argillaceous Sediments. Part 1. Origin and Significance of Clay Minerals in Sedimentary Rocks. American Association of Petroleum Geologists Bulletin, 42, 254-271.

[44] Curray, J.R. (1994) Sediment Volume and Mass beneath the Bay of Bengal. Earth and Planetary Science Letters, 125, 371-383. https://doi.org/10.1016/0012-821X(94)90227-5

[45] Gani, M.R. and Alam, M.M. (1999) Trench-Slope Controlled Deep-Sea Clastics in the Exposed Lower Surma Group in the Southeastern Fold Belt of the Bengal Basin, Bangladesh. Sedimentary Geology, 127, 221-236. https://doi.org/10.1016/S0037-0738(99)00050-0

[46] Uddin, A. and Lundberg, N. (2004) Miocene Sedimentation and Subsidence during Continent-Continent Collision, Bengal Basin, Bangladesh. Sedimentary Geology, 164, 131-146. https://doi.org/10.1016/j.sedgeo.2003.09.004

[47] Najman, Y., Allen, R., Willett, E.A.F., Carter, A., Barfod, D., Garzanti, E. and Oliver, G. (2012) The Record of Himalayan Erosion Preserved in the Sedimentary Rocks of the Hatia Trough of the Bengal Basin and the Chittagong Hill Tracts, Bangladesh. Basin Research, 24, 499-519. https://doi.org/10.1111/j.1365-2117.2011.00540.x

[48] Gansser, A. (1964) Geology of the Himalayas.

[49] Johnson, S.Y. and Alam, A.M.N. (1991) Sedimentation and Tectonics of the Sylhet Trough, Bangladesh. Geological Society of America Bulletin, 103, 1513-1527. https://doi.org/10.1130/0016-7606(1991)103<1513:SATOTS >2.3.CO;2

[50] Gani, M.R. and Alam, M.M. (2003) Sedimentation and Basin-Fill History of the 
Neogeneclastic Succession Exposed in the Southeastern Fold Belt of the Bengal Basin, Bangladesh: A High-Resolution Sequence Stratigraphic Approach. Sedimentary Geology, 155, 227-270. https://doi.org/10.1016/S0037-0738(02)00182-3

[51] Najman, Y., Bickle, M., BouDagher-Fadel, M., Carter, A., Garzanti, E., Paul, M. and Akhter, S.H. (2008) The Paleogene Record of Himalayan Erosion: Bengal Basin, Bangladesh. Earth and Planetary Science Letters, 273, 1-14. https://doi.org/10.1016/j.epsl.2008.04.028

[52] Rahman, M.J.J. and Faupl, P. (2003) ${ }^{40} \mathrm{Ar} / \mathrm{Ar}^{39}$ Multigrain Dating of Detrital White Mica of Sandstones of the Surma Group in the Sylhet Trough, Bengal Basin, Bangladesh. Sedimentary Geology, 155, 383-392.

[53] Rahman, M.J.J. and Suzuki, S. (2007) Geochemistry of Sandstones from the Miocene Surma Group, Bengal Basin, Bangladesh: Implication for Provenance, Tectonic Setting and Weathering. Geochemical Journal, 41, 415-428. https://doi.org/10.2343/geochemj.41.415

[54] Bauluz, B., Mayayo, M.J., Fernandez-Nieto, C. and Gonzalez-Lopez, J.M. (2000) Geochemistry of Precambrian and Paleozoic Siliciclastic Rocks from the Iberian Range (NE Spain): Implications for Source Area Weathering, Sorting, Provenance, and Tectonic Setting. Chemical Geology, 168, 135-150. https://doi.org/10.1016/s0009-2541(00)00192-3

[55] Mielke, J.E. (1979) Composition of the Earth's Crust and Distribution of the Elements. In: Siegel, F.R., Ed., Review of Research on Modern Problems in Geochemistry, Paris, International Association for Geochemistry and Cosmochemistry, Earth Science Series, 16, 13-37.

[56] Einsele, G. (1992) Sedimentary Basins. Springer Verlag, Berlin, 628 p. https://doi.org/10.1007/978-3-642-77055-5

[57] Dalai, T.K., Krishnaswami, S. and Sarin, M.M. (2002) Major Ion Chemistry in the Headwaters of the Yamuna River System: Chemical Weathering, Its Temperature Dependence and $\mathrm{CO}_{2}$ Consumption in the Himalaya. Geochimica et Cosmochimica Acta, 66, 3397-3416. https://doi.org/10.1016/s0016-7037(02)00937-7

[58] Cullers, R., Chaudhuri, S., Kilbane, N. and Koch, R. (1979) Rare-Earths in Size Fractions and Sedimentary Rocks of Pennsylvanian-Permian Age from the MidContinent of the USA. Geochimica et Cosmochimica Acta, 43, 1285-1301.

[59] McLennan, S.M. (2001) Relationships between the Trace Element Composition of Sedimentary Rocks and Upper Continental Crust. Geochemistry, Geophysics, Geosystems, 2, 1021. https://doi.org/10.1029/2000GC000109

[60] McCann, T. (1991) Petrological and Geochemical Determination of Provenance in the Southern Welsh Basin. Geological Society, London, Special Publications, 57, 215-230. https://doi.org/10.1144/GSL.SP.1991.057.01.17

[61] Rimmer, S.M. (2004) Geochemical Paleoredox Indicators in Devonian-Mississippian Black Shales, Central Appalachian Basin (USA). Chemical Geology, 206, 373 391. https://doi.org/10.1016/j.chemgeo.2003.12.029

[62] Nagarajan, R., Madhavaraju, J., Nagendra, R., Armstrong-Altrin, J.S. and Moutte, J. (2007) Geochemistry of Neoproterozoicshales of the Rabanpalli Formation, Bhima Basin, Northern Karnataka, Southern India: Implications for Provenance and $\mathrm{Pa}$ leoredox Conditions. Revista Mexicana de Ciencias Geológicas, 24, 150-160.

[63] Dypvik, H. (1984) Geochemical Compositions and Depositional Conditions of Upper Jurassic and Lower Cretaceous Yorkshire Clays, England. Geological Magazine, 121, 489-504. https://doi.org/10.1017/S0016756800030028

[64] Dill, H. (1986) Metallogenesis of Early Paleozoic Graptolite Shales from the Grae- 
fenthal Horst (Northern Bavaria-Federal Republic of Germany). Economic Geology, 81, 889-903. https://doi.org/10.2113/gsecongeo.81.4.889

[65] Breit, G.N. and Wanty, R.B. (1991) Vanadium Accumulation in Carbonaceous Rocks: A Review of Geochemical Controls during Deposition and Diagenesis. Chemical Geology, 91, 83-97. https://doi.org/10.1016/0009-2541(91)90083-4

[66] Hallberg, R.O. and Халлберг, Р.O. (1976) A Geochemical Method for Investigation of Paleoredox Conditions in Sediments/Геохимическийметодисследований у.

[67] Somayajulu, B.L.K., Rengarajan, R. and Jani, R.A. (2002) Geochemical Cycling in the Hooghly Estuary, India. Marine Chemistry, 79, 171-183.

https://doi.org/10.1016/S0304-4203(02)00062-2

Submit or recommend next manuscript to SCIRP and we will provide best service for you:

Accepting pre-submission inquiries through Email, Facebook, LinkedIn, Twitter, etc. A wide selection of journals (inclusive of 9 subjects, more than 200 journals)

Providing 24-hour high-quality service

User-friendly online submission system

Fair and swift peer-review system

Efficient typesetting and proofreading procedure

Display of the result of downloads and visits, as well as the number of cited articles

Maximum dissemination of your research work

Submit your manuscript at: http://papersubmission.scirp.org/

Or contact gep@scirp.org 